\title{
The Transfer Problem Surfaces in Sub-Saharan Africa: Net Foreign Assets, Financial Liberalization and Real Exchange Rates
}

\author{
OYAKHILOME IBHAGUI* \\ BT Research - Economics and Finance Research Group
}

\begin{abstract}
This paper presents new links among net foreign assets (NFA), financial liberalization, and the real exchange rates in Sub-Saharan Africa (SSA), utilizing a testable theoretical model inspired by Lane and Milesi-Ferreti (2004) and newly constructed data sets for real exchange rates, net foreign assets, and financial liberalization. First, we check for the existence of a transfer problem - the hypothesis that increases in NFA strengthen the real exchange rates. Second, we examine how real exchange rates have reacted to financial liberalization in SSA. Finally, we explore whether financial liberalization dampens the effects of a transfer problem. Empirical analysis, using cross-country data, confirms the existence of a transfer problem that decreases with increases in trade openness in SSA. We also find that, overall, countries with financial liberalization have more depreciated real exchange rates and that financial liberalization dampens the transfer problem so that the semi-elasticity of NFA becomes negative, implying that financially liberalized SSA countries that experience an increase in net external liabilities would eventually require an appreciated, rather than depreciated, real exchange rate. The results are robust to various model specifications and estimation techniques, inclusion of other determinants of real exchange rates and consideration of endogeneity.
\end{abstract}

Keywords: Transfer effect, net foreign assets, real exchange rates

JEL Classification Codes: F31, F41

\section{Introduction}

The real exchange rates, though an important variable in international macroeconomics, remain a tough nut to crack because a full grasp of its determinants or drivers has often eluded researchers for decades. Despite much research, there is no consensus on which variables explain or drive real exchange rates movements. The paragraph below, an excerpt from Baxter (1994), remains as relevant today as it was several decades ago.

(C) 2019 Oyakhilome Ibhagui ; . Licensed under the Creative Commons Attribution - Noncommercial 3.0 Licence (http://creativecommons.org/licenses/by-nc/3.0/. Available at http: //rofea.org. 
“......Second, there is the empirical problem of discovering the underlying causes of movements in real exchange rates...... An early contribution to this literature is Barro (1983); Baxter (1993) also investigated whether an array of policy variables could explain ... movements in these variables. Both of these studies failed to find policy variables or other macroeconomic variables which could explain movements in real exchange rates ...... Thus, it remains an open empirical problem to discover the underlying determinants/drivers of real exchange rates ...."

Economists widely document and collectively agree that the evolution of real exchange rates provides useful information about important characteristics of economies and serves as a leading indicator of economic strength because important economic variables such as foreign investment, capital flows or international trade, among others, are influenced by the consequences that movements in real exchange rates confer on goods and financial markets. Although interesting, it is not our aim in this paper to study the important and lasting consequences of real exchange rates' evolution on macroeconomic variables. Instead, we are more interested in what drives the real exchange rates and how these factors drive the real exchange rates. Understanding real exchange rates drivers and determinants can help explain the root causes of their behavior. Moreover, our interest becomes even more pronounced when one realizes that an often-asked question 'what variables determine the behavior of real exchange rates in SSA' has yet to receive an answer. Thus, this paper empirically explores real exchange rates drivers in SSA, utilizing a theoretical benchmark model that builds on existing real exchange rates determinants, particularly examining the factors responsible for real exchange rates behavior in SSA. Two major questions this paper answers are whether there is an evidence of a transfer effect in SSA and how the adoption of financial liberalization in SSA has impacted real exchange rates in countries in the region.

Our empirical results show that while financial liberalization has significantly weakened real exchange rates, net foreign asset has led to real exchange rates appreciation in SSA, confirming the presence of a significant transfer effect. Also, we find that real interest rates differentials increase real exchange rates and since our data samples are low frequency, i.e. yearly data, this result agrees with the findings of Baxter (1994). In addition, the results provide evidence that financial liberalization shrinks and reverses the positive impact of net foreign assets on real exchange rates. This suggests that financial liberalization dampens the impact of a transfer effect. That is, with more financial liberalization, SSA countries are purged of the influence of the transfer effect as a net external liabilities position, for instance, which would normally attract a real depreciation in the presence of a functional transfer effect, would no more do so. These results are robust to different empirical specifications and estimation techniques employed. Thus, consideration of financial liberalization is crucial in the study of 
transfer effects, and to the best of our knowledge this has not been shown before. The panel regressions also show that the size of the transfer effect is related to country characteristics such as trade openness; on average, the transfer effect decreases as SSA countries become more open, as predicted by the theory model presented in the paper. Less promising are our results on the response of real exchange rates to terms of trade and relative real output. Although we find sparse evidence that terms of trade and relative per capita output each increases real exchange rates in line with the model, in general this result is either inconsistent, non-robust and switches signs across different specifications and estimation techniques employed or is outright insignificant ${ }^{1}$.

At its core, the process of financial liberalization involves the removal of government restrictions or interventions in the financial markets. This process is often gradual. The rationale for removal of restrictions include a desire to foster financial development and enhance growth, amongst others. In general, a large amount of studies has investigated the consequences of financial liberalization on an almost exhaustive list of macroeconomic variables and their policy implications for countries especially following the eschewing of financial repression and adoption of financial liberalization by a large number of countries in Europe, Africa, Asia and South America. In most of these studies, economic growth has been the main macroeconomic variable on which the impact of financial liberalization is studied. For instance, see McKinnon (1973) and Shaw (1973), Bekaert et al. (2005), Stiglitz (2000) and Gehringer (2013), among very many others. The rationale behind these studies is to determine whether adopting financial liberalization has directly led to higher growth and economic prosperity in different countries and regions. Another strand of studies, such as Ranciere, Tornell and Westermann (2005), Tornell et.al (2003) and Kaminsky and Reinhart (1999), have looked at the role of financial liberalization in financial crises.

There are also studies which have examined the response of real exchange rates to economic variables, including productivity differentials, foreign aid, real interest rates, current account and its constituents as well as international payments, see Balassa, Samuelson $(1964,1964)$, Krugman (1987), Meese and Rogoff (1988) and Lane and Milesi-Ferretti (2002). However, despite the growing global influence of financial liberalization, beginning from the 1970's at the minimum in developed countries and the 1980's and 1990's in developing countries, as well as the highly reactive nature of real exchange rates to new policies and reforms, especially in developing countries such as those in SSA, a detailed study on how financial liberalization influences real exchange rates is scarce and, in most extreme instances, non-existent. To further buttress this scarcity, comprehensive studies on the drivers of real exchange rates, especially

\footnotetext{
${ }^{1}$ It is important to note that the relative per capita output variable used in this study is the per capita output of a country relative to the weighted values of those of its trading partners, where the weights sum to 1 and the highest trading partner is assigned the largest weight while the least trading partner assigned the least weight.
} 
their fundamental drivers and determinants, have received much less attention, more so in subSaharan Africa (SSA).

Regarding the existence of transfer effects, most existing studies have focused almost exclusively on Keynes's original argument that, in investigating the existence of a transfer effect, terms of trade are endogenous rather than exogenous determinant of real exchange rates ${ }^{2}$. Using data samples for Latin American countries, Broner et al. (1997) estimate real exchange rates regressions to ascertain the determinants of real exchange rates. Their theoretical model allows net foreign assets as a fraction of GNP to affect real exchange rates through its effect on terms of trade. Thus, they consider terms of trade as an endogenous determinant of real exchange rates. Under this specification, they find a significant positive relationship between real exchange rates and net foreign assets for some, but not all, countries in their sample. The positive link between net foreign assets and real exchange rates confirms the existence of a transfer problem ${ }^{3}$ - the hypothesis that countries with net foreign assets have more appreciated real exchange rates. The appreciation, which stems from inflows - the receipt of principal and interest on net foreign assets from debtor countries (see Girardi and Paesani (2008)), implies that the value of the net foreign assets would decrease, in domestic terms, causing a fall in external wealth, in domestic terms, for creditor countries. The transfer problem also implies a negative relationship between net foreign liabilities and real exchange rates, so that countries with net foreign liabilities have more depreciated real exchange rates stemming from outflows - the repayment of principal and interest on net foreign liabilities to creditor countries. The depreciation causes the value of net foreign liabilities to swell even further, in domestic terms, making debtor countries to appear more debt-burdened.

Following a specification like Broner et al. (1997), Alberola et al. (1999) estimate equilibrium exchange rates for a set of industrial countries under the assumption that terms of trade, in large parts, are endogenously determined. The issue with such an assumption is that, for small open economies such as SSA, the assumption appears too strong and somewhat unrealistic - the reason being that the degree of endogeneity of terms of trade for small open economies is extremely low or non-existent given the small sizes of these economies and consequently their inability to enact domestic policies that influence international prices significantly. Hence, they are price takers. For these small open economies, terms of trade are largely determined exogenously and thus should be conveniently included as exogenous

\footnotetext{
2 Keynes's original argument considers terms of trade as the main mechanism through which international payments affect real exchange rates.

${ }^{3}$ The problem of establishing positive long-run relationship between international payments, proxied by net foreign assets, and real exchange rates is known as the transfer problem. It is a problem because its presence can lead to consistent real appreciations and might cause countries' net foreign assets to be worth less, in domestic terms, or tradable sectors to lose their edge. Although popular, it is a problem which very few studies have attempted to address in different regions. Moreover, it remains to be studied in the context of SSA as no study, to the best of our knowledge, has addressed the link between real exchange rates and net foreign assets of SSA countries.
} 
determinants of real exchange rates whilst controlling for their effects. This way, any identified determinants of real exchange rates will impact real exchange rates not through terms of trade, which have been taken as exogenously determined and duly controlled for, but through other mechanisms such as the relative price of non-tradables. This idea, emphasized in Lane and Milesi-Ferretti (2004), forms the foundation of the model on which our empirical analysis is benchmarked in this paper.

There are other earlier studies that have examined the net foreign assets and real exchange rate nexus. In an influential study, Obstfeld and $\operatorname{Rogoff}(1995,1996)$ estimate a cross-sectional bivariate regression of real exchange rates on net foreign assets for industrial countries. Their results yield a significantly positive coefficient of net foreign assets, around unity, implying that net foreign assets positively drive real exchange rates in industrial countries. Faruqee (1995), in a time series framework, estimates a set of real exchange rates equations on post-war data of United States and Japan. The set-up includes variables such as real exchange rates, terms of trade, CPI-to-WPI ratio and net foreign assets as a proportion of GDP. The results obtained suggest a positive and significant relationship between net foreign assets and real exchange rates. Because they control for both terms of trade and relative price of nontraded goods, their results suggest that net foreign assets must be impacting real exchange rates through other mechanisms - other than through terms of trade and/or relative price of nontradables since both variables are held fixed, included in the regression and controlled for as exogenous determinants. Thus, they conclude that structural factors underlying each country's net trade and net foreign asset positions determine the behaviour of real exchange rates, meaning these variables explain exchange rates behaviour through the underlying structural factors. Gagnon (1996) studies the long-run relationship between real exchange rates and net foreign assets in a panel data context with a focus on industrial countries. He finds a positive relationship between real exchange rates and net foreign assets, suggesting that net foreign assets are a positive determinant of real exchange rates behaviour. However, similar to Faruquee (1995), Gagnon (1996) hold fixed the relative price of nontraded goods by controlling for its effect via including it as an exogenous determinant of real exchange rates in their analysis.

Other studies such as Kakkar and Yan (2014) show that productivity differential, or the Balassa-Samuelson hypothesis, alongside real interest rate differential and real value of gold, is responsible for the observed behaviour of real exchange rates in OECD countries. Christopoulous et al (2012) find that real exchange rates are driven by productivity and net foreign assets in financially constrained countries, and productivity alone in financially unconstrained countries. While Lane and Milesi-Ferretti (2004) conclude that real exchange rates behaviour in industrialized economies is related to changes in net foreign assets, terms of trade and productivity differential, they are unable to find a conclusive evidence for such relationships for developing economies. 
In this paper, rather than allow identified economic variables to determine real exchange rates through terms of trade while holding fixed the relative price of nontradables, we instead emphasize the relative price of nontradables as the mechanism through which identified economic variables and factors impact real exchange rates. This framework, which is in the spirit of Lane and Milesi-Ferretti (2004), differs from other studies because it highlights the relative price of nontradables channel as the medium through which identified variables explain real exchange rates ${ }^{4}$. Thus, in our setup, terms of trade are taken as exogenously determined. Our empirical analysis focuses on SSA because to date no comprehensive research addressing the questions posed in this paper currently exists even though net foreign assets have grown or shrunk over time and decades have passed since financial liberalization gained prominence and acceptance in SSA countries. We suspect the paucity of data on real exchange rates hitherto is partly responsible for the lack of comprehensive research contributions in this area. We therefore seek to fill this void by turning to the newly constructed real exchange rates data sets and samples in Darvas $(2012,2016)$. Darvas $(2012,2016)$ provides a comprehensive database of CPI-based real effective exchange rates for 178 countries covering well over three decades. The estimates are good - in the few instances where real effective exchange rates data samples are available from the World Bank and IMF Databases for SSA countries, they match the estimates in Darvas $(2012,2016)$ almost perfectly. We also use the updated and extended version of Lane and Milesi-Ferretti (2007) newly constructed dataset on countries' net external positions, to shed new light on the question of determining real exchange rates drivers in SSA. By exploiting these new data samples, this paper fills a void and analyses the impact of financial liberalization and determinants of the real exchange rates across SSA.

To perform the aforesaid analysis, we utilize a 2-sector model of real exchange rates, the Lane and Milesi-Ferretti (2004) model that contains three determinants of real exchange rates - relative productivity, net foreign assets and terms of trade, representing real shocks, assetmarket shocks, and trade shocks, respectively. While these variables serve as potential drivers of real exchange rates, they do not capture other possible economic variables that could influence real exchange rates in SSA. Considering this, we include into our empirical analysis financial liberalization and real interest rate differentials as possible determinants of real exchange rates behavior in SSA. We proxy financial liberalization using a dummy variable which takes a value of one from the year in which countries adopt financial liberalization and zero elsewhere. Our model thus considers possible variables that can influence real exchange rates in SSA. How these variables link with real exchange rates in SSA is ultimately an

\footnotetext{
${ }^{4}$ The need to emphasize the relative price of nontradables stems from the implications of the traditional real exchange rate theory, whose origin dates back to the work of Cassel (1918) and Pigou (1923), which finds that movements in real exchange rates are due to endogenous fluctuations in the relative price of non-traded to traded goods. Also, Betts and Kehoe (2008), Burstein et al (2005) and Ouyang and Rajan (2013) all find that much of the directional movements of the relative price of non-traded goods and the real exchange rates tend to be similar, although the finding might be sensitive to countries considered.
} 
empirical question which we answer in this paper. We perform an empirical analysis to study the determinants of real exchange rates in SSA, where we choose countries based, among others, on data availability which allows us to analyze the economic variables in terms of their short-run and long-run effects on real exchange rates.

To summarize the results, this paper sheds light and offers a new insight on the drivers of real exchange rates in SSA by combining two strands of empirical and theoretical work. The first strand focuses on real economic variable, relative per capita output, as suggested by the Balassa-Samuelson model, whereas the second strand emphasizes global demand, goods and asset-market variables such as terms of trade, net foreign assets, and real interest rates differentials. We propose a third factor, financial liberalization, which may affect real exchange rates and proxy this factor using dummy variables which take 1 when countries embraced liberalization and zero otherwise, where financial liberalization can be regarded as a source of shocks to global financial system/capital flows. Four major issues are then addressed in this paper. One, we test and then extend, in an empirical set up, the Lane and Milesi-Ferretti (2004) model to include financial liberalization and real interest rates differentials and empirically investigate the determinants of real exchange rates behavior in SSA under this framework. Two, we use a broad range of SSA countries which allow us to investigate the hypothesized drivers of real exchange rates. Third, we control for terms of trade and emphasize the relative price of nontradables as the main channel of transmission of the effects of the identified variables, determinants or factors to real exchange rates. Controlling for terms of trade allows the identified variables to impact real exchange rates not through the terms of trade as is customary in some studies but through the relative price of nontradables in the spirit of Lane and MilesiFerreti (2004).

Our findings have presented evidence supporting the existence of a small but significant transfer effect in SSA and that adoption of financial liberalization has depreciated the real exchange rates across SSA. Even after controlling for real interest rates differentials, relative output levels and the terms of trade, empirical evidence continues to suggest the existence of a robust positive relationship between net foreign assets and real exchange rates and a negative relationship between financial liberalization and real exchange rates, with net debtor countries having a more depreciated real exchange rates ceteris paribus and a more appreciated real exchange rates with the adoption of financial liberalization. Furthermore, we empirically confirm the theoretical postulates in Lane and Milesi-Ferreti (2004) that the magnitude of transfer effects varies with country characteristics such as openness. An especially interesting finding is that financial liberalization reduces and ultimately eliminates and reverses the effects of a transfer problem. This evidence is relevant to the current and ever ongoing policy debates on financial liberalization in many SSA countries. The rest of the paper is organized as follows. Section 2.2 - 2.6 presents the theoretical framework. Section $2.7-2.9$ describes in detail the 
newly constructed data that enabled the empirical research presented in this paper, presents and discusses the empirical results for cross-section and panel data and provides comparison with similar existing empirical studies. Section 2.10 concludes with pointers to possible future extension.

\subsection{The Model}

In this section, we briefly describe the two-sector model of Lane and Milesi-Ferreti (2004) which we use for analyzing the behavior of real exchange rates. The model is an intertemporal optimizing model in which an endogenous relative price of nontradables is the mechanism linking the real exchange rates to their determinants. We derive the steady state model based on this framework and test the implications of the theoretical model in an empirical setting 5 . Our main addition to the model is in explicitly deriving the sensitivity of the transfer effect to variations in openness for different scenarios of the intertemporal and intratemporal elasticities of substitution.

To begin, consider a small open economy (SOE) that produces goods and has a representative infinitely-lived household that consumes goods according to established preferences represented by a utility function in an objective function $\aleph_{i}$. The small open economy comprises tradable and nontradable sectors and thus produces tradable and nontradable goods. The output of the tradable sector is an endowment $Y_{T}$ that trades on the international market at an export price $P_{T}^{1}$, where $P_{T}^{1}$ is in units of the imported tradable consumption good, which is the numeraire. As a result, $P_{T}^{1}$ represents terms of trade, i.e. ratio of export to import prices. Export goods are not consumed domestically, so domestic consumption of export goods is zero. Although labour can be supplied across traded and nontraded sectors, it is assumed that labour is supplied competitively only to the nontraded sector. This assumption ensures that it is possible to emphasize the main relationships which are to endogenize the relative price of nontradables and use it as the mechanism linking the real exchange rates to their identified determinants. Following Lane (1999), we model utility as having a CRRA form in aggregate consumption while aggregate consumption is itself taken to be a CES index over consumption of traded and nontraded goods. As will be made clear in the subsequent sections, this general specification ensures that we are able to capture the different kinds of responses of current and future consumption, as well as substitutability between traded and nontraded goods, to changes in current and future aggregate price levels.

\footnotetext{
${ }^{5}$ We illustrate how real exchange rates might be influenced by their determinants by briefly describing the Lane and Milesi-Ferreti (2004) model, which we use as the benchmark for our extended empirical work.
} 


\subsubsection{Households}

The infinitely-lived household with a perfect foresight derives utility from consumption $C_{t}$ and disutility from labour $L_{N t}$ supplied to the competitive nontraded sector. The lifetime objective function of the infinitely-lived household is thus

$$
\aleph_{i}=\sum_{t=0}^{\infty} \beta^{t}\left[\frac{\sigma}{\sigma-1} C_{t}^{\frac{\sigma-1}{\sigma}}-\frac{\vartheta}{1+\varphi} L_{N t}^{1+\varphi}\right], 0<\beta<1 \text { and } \sigma, \vartheta, \varphi>0
$$

where $L_{N t}$ represents the actual amount of labour supplied to the nontraded sector, $\sigma$ is the constant relative risk aversion (CRRA) parameter $^{6}$ and $\beta$ is the household's discount factor. All parameters are positive and the last term in the utility function captures the disutility, in terms of reduced leisure, of supplying an amount $L_{N t}$ of labour to the nontraded sector. Specifically, the last term captures the disutility of labour or work effort, where $\varphi>0$ represents the inverse of the Frisch elasticity of labour supply with respect to the real wage.

The household can invest in international real bonds, denominated in units of imported goods, in the world markets, without restrictions. Suppose the household invests in a combination of international real bonds. Let $B_{t}$ denote net real bond holdings, in units of tradable goods, which generate an exogenously determined real return $r$. The household supplies labour $L_{N t}$ to the nontraded sector at a nominal rate of $w_{t}$ per unit labour and thus earns a nominal wage of $w_{t} L_{N t}$ for labour supplied. The representative household faces a flow budget constraint given by

$$
B_{t+1}=(1+r) B_{t}+w_{t} L_{N t}+P_{T t}^{1} Y_{T}-P_{t} C_{t}
$$

where $C_{t}$ represents the consumption index, while $B_{t+1}$ is the real bond holdings in the next period and $B_{t}$ denotes real bonds that pay off an exogenously given real return $r$. Obstfeld and Rogoff (1996) timing convention is adopted so that $C_{t}$ denotes the consumption index between period $t$ and period $t+1$, while $B_{t}$ denotes bonds between period $t-1$ and $t$.

The aggregate consumption index $C_{t}$ is a composite of traded $C_{T t}$ and nontraded $C_{N t}$ goods. The consumption index is defined as

$$
C_{t}=\left[\mu^{\frac{1}{\rho}} C_{T t}^{\frac{\rho-1}{\rho}}+(1-\mu)^{\frac{1}{\rho}} C_{N t}^{\frac{\rho-1}{\rho}}\right]^{\frac{\rho}{\rho-1}}, \quad \rho>0
$$

\footnotetext{
${ }^{6}$ Intertemporal elasticity of substitution is the reciprocal of the CRRA parameter given by $\frac{1}{\sigma}$
} 
where $\rho$ measures the constant elasticity of substitution (CES) between traded $\left(C_{T t}\right)$ and nontraded $\left(C_{N t}\right)$ goods, and $\mu$ is the share of tradable goods in the domestic consumption basket. In this context, the price index that corresponds to the consumption index is the consumption price index $P_{t}$ given by ${ }^{7}$

$$
P_{t}=\left[\mu+(1-\mu) P_{N t}^{1-\rho}\right]^{\frac{1}{1-\rho}}
$$

where $P_{N t}$ is the price of nontradable goods ${ }^{8}$. From (2.2) and (2.3), the demand functions for the tradable and nontradable goods are given by

$$
C_{T t}=\mu\left(\frac{1}{P_{t}}\right)^{-\rho} C_{t}, \quad C_{N t}=(1-\mu)\left(\frac{P_{N t}}{P_{t}}\right)^{-\rho} C_{t},
$$

The real exchange rate is then defined as in Lane and Milesi-Ferreti (2004) as the ratio of domestic consumption price index $(\mathrm{CPI})$ to foreign consumption price index $(\mathrm{CPI})$

$$
R E R_{t} \equiv \frac{P_{t}}{P_{t}^{f}}=P_{t}
$$

where the foreign CPI is normalized to unity and held at this level throughout the analysis.

As (2.5) shows, the CPI-based real exchange rate is independent of terms of trade. Nonetheless, it is possible for terms of trade to affect the CPI-based real exchange rates if there were an unusually high home bias in consumption of tradables. In such a scenario, domestic price levels would largely reflect price levels of tradable goods, because of the high home bias for the consumption of tradables, so that $P_{t} \sim P_{T}^{1}$. In this model, however, it is assumed that tradable goods are not consumed domestically, so no such bias exists. Instead, the real exchange rates may be influenced by terms of trade only indirectly, through a wealth effect on the relative price of nontradables. Indeed, a transfer from home to foreign country reduces domestic wealth and hence raises labour supply to the nontradables sector. The increase in labour supply to the nontradables sector increases the supply of nontradables, thereby affecting relative prices of nontradables and hence the CPI-based real exchange rates.

\footnotetext{
${ }^{7}$ Notice that the consumption price index does not include the price of the traded goods because the export goods, though consumed, is not consumed domestically, so its price cannot impact the domestic consumption price index; moreover, we want to emphasize that the real exchange rate is affected through the relative price of nontradables.

${ }^{8}$ Prices are for goods sold in the home country, in home currency and at the consumer level, for nontradable goods, since domestic consumption of export, tradable goods is zero.
} 
Output supplied at time $t$ in the competitive nontraded sector is taken as a production function that is linear in labour,

$$
Y_{N t}=L_{N t}
$$

while the nominal price of the nontradable good is taken as equivalent to the nominal wage

$$
P_{N t}=w_{t}
$$

\subsection{First-order conditions}

The intertemporal problem of the infinitely-lived household is to maximize lifetime objective function, $\aleph_{i}$, subject to (2.1) - (2.6). To simplify the model and option tractable first order optimality conditions, it is assumed the economy faces no uncertainty, which makes for a deterministic case in which there is a substantial amount of perfect foresight. We derive the optimality conditions as follows. The Lagrangian $L$ is given by

$$
\begin{aligned}
L & =\max \sum_{t=0}^{\infty}\left\{\beta^{t}\left[\frac{\sigma}{\sigma-1} C_{t}^{\frac{\sigma-1}{\sigma}}-\frac{\vartheta}{1+\varphi} L_{N t}^{1+\varphi}\right]\right. \\
& +\beta^{t} \lambda_{t}\left((1+r) B_{t}+w_{t} L_{N t}+P_{T t}^{1} Y_{T}-P_{t} C_{t}\right. \\
& \left.\left.-B_{t+1}\right)\right\}
\end{aligned}
$$

which yields the following first-order conditions

$$
\left\{\begin{array}{c}
\frac{\partial L}{d C_{t}}=C_{t}^{-\frac{1}{\sigma}}-P_{t} \lambda_{t}=0 \\
\frac{\partial L}{\partial B_{t+1}}=-\lambda_{t}+\beta(1+r) \lambda_{t+1}=0 \\
\frac{\partial L}{\partial \lambda_{t}}=(1+r) B_{t}+w_{t} L_{N t}+P_{T t}^{1} Y_{T}-P_{t} C_{t}-B_{t+1}=0 \\
\frac{\partial L}{\partial L_{N}}=-\vartheta L_{N t}^{\varphi}+\lambda_{t} w_{t}=0
\end{array}\right.
$$

Under the simple assumption that $\beta(1+r)=1$, so that the desire to borrow and lend in the steady state is ruled out, the optimal consumption and labour supply decisions generate the following first order relationships 


$$
\left\{\begin{array}{c}
\frac{C_{T t+1}}{C_{T t}}=\left(\frac{P_{t}}{P_{t+1}}\right)^{\sigma-\rho} \\
\frac{C_{N t}}{C_{T t}}=\frac{(1-\mu)}{\mu}\left(P_{N t}\right)^{-\rho} \\
Y_{N t}=L_{N t}=\left(\frac{1}{\vartheta} C_{t}^{-\frac{1}{\sigma}} \frac{P_{N t}}{P_{t}}\right)^{\frac{1}{\varphi}}
\end{array}\right.
$$

The first order conditions provide several important insights. The first equation in (2.10) is the Euler equation of the dynamic evolution of consumption under perfect foresight. It says that consumption grows at a rate proportional to the sequence of relative aggregate prices; the dependence of consumption growth on the sequence of relative prices is a well-known result which is the consumption-based real interest rate effect. In particular, if the aggregate price level relative to the price of traded goods is currently below its future value, this induces increases in present consumption relative to future consumption due to lower consumptionbased real interest rate. However, depending on the values of the intertemporal and intratemporal substitution, the low aggregate price level might encourage substitution from traded to nontraded goods. This substitution would occur and be more dominant when the intratemporal elasticity of substitution is greater than the intertemporal elasticity of substitution. Otherwise, the former effect dominates. The second equation in (2.10) provides a link between consumption of traded and nontraded goods, as well as the relative price of nontraded goods and the intratemporal elasticity of substitution. If the relative price of nontradables is normalized to unity, the relative consumption of traded goods would increase the greater the value of $\mu$ as $\frac{\partial C_{T t}}{\partial \mu}=\frac{C_{N t}}{(1-\mu)^{2}}>0$, which implies higher $\mu$ gives rise to higher consumption of tradable goods, where $\mu$ represents the size of the tradable sector. Whereas it decreases the smaller is the value of $\mu$, leading to an increase in the relative consumption of nontraded goods. Put differently, the relative consumption of nontraded goods decreases as the size of the tradable sector increases, and it increases as the size of the tradable sector reduces, since $\frac{\partial C_{N t}}{\partial \mu}=-\frac{C_{T t}}{\mu^{2}}<$ 0 . Finally, the last equation in (2.10) gives the equilibrium supply of nontraded goods alongside labour supply to the nontraded sector. It shows that as consumption index increases, whether due to an increase in the consumption of nontraded goods, labour supplied to the nontraded sector decreases and hence the level of production of nontradables also decreases. Plausible explanation for this outcome is that household increases leisure and consumption of other goods. The increase in leisure reduces the amount of labour supplied to the nontraded sector. Since production in the nontraded sector is linear in labour, the decrease in labour, together with the increase in consumption of other goods, causes a scale-back in the level of production. 


\section{IBHAGUI Transfer Problem in Sub-Saharan Africa}

\subsection{The Steady State Analysis}

As in Ganelli (2004) and Lane and Milesi-Ferreti (2004), we first consider a benchmark steady state where the variables are constant. To preserve symmetry, we consider an initial steady state in which all variables are constant. In this reference steady state, we assume the stock of net foreign assets is zero and we normalise the endowment of the traded goods in such a way that $P_{N}$, the relative price of nontraded goods in terms of traded goods, is unity. Furthermore, it is assumed that the terms of trade is unity $\left(P_{T}^{1}=1\right)$. A summary of the implications of the benchmark steady-state assumptions is given below

$$
\left\{\begin{array}{c}
B_{0}=0, \quad P_{N}=1, \ldots P=1, \ldots P_{T}^{1}=1 \\
C_{T}=Y_{T}, C_{N}=Y_{N}
\end{array}\right.
$$

After normalizing the endowment of traded goods, so that the relative price of nontraded goods in terms of traded goods $P_{N}$ is unity, and assuming the terms of trade is unity, then the steadystate production and consumption of traded and nontraded goods in this symmetric equilibrium are given by

$$
\left\{\begin{array}{l}
C_{T}=Y_{T}=\frac{\mu}{1-\mu} Y_{N} \\
Y_{N}=C_{N}=\left(\frac{1}{\vartheta}\right)^{\frac{\sigma}{\sigma \varphi+1}}(1-\mu)^{\frac{1}{1+\sigma \varphi}}
\end{array}\right.
$$

The first equation of (2.12) follows from using the second equation of (2.10) together with the assumptions in (2.11). The second equation of (2.12) uses the assumptions in (2.11) together with the budget constraint in (2.1) and the first equation of (2.12).

We note that $\vartheta$ measures how tasking is work effort, so higher (lower) values of $\vartheta$ imply work effort is more (less) tasking. The second equation in the benchmark steady state in (2.12) shows that production of nontraded goods will be larger when work effort is less tasking as, $\frac{\partial Y_{N}}{\partial \vartheta}=$ $-\frac{\sigma}{\varphi \sigma+1} \frac{Y_{N}}{\vartheta}<0$. It also implies that production of nontraded goods will expand when either the size of the tradable sector shrinks or the size of the nontradable sector expands. This follows from the result that for $\mu<1, \frac{\partial Y_{N}}{\partial \mu}=-\frac{1}{\varphi \sigma+1} \frac{Y_{N}}{1-\mu}<0$ and $\frac{\partial Y_{N}}{\partial(1-\mu)}=\frac{1}{\varphi \sigma+1} \frac{Y_{N}}{1-\mu}>0$, where $\mu$ and $1-\mu$ represent the size of tradable and nontradable sector, respectively.

The above benchmark specification allows us to derive the steady state variations in important variables of the model. To do this, we take a linear approximation around the benchmark to derive the impact of steady state variations in net foreign assets, $B$, tradable 
output, $Y_{T}$, and terms of trade $P_{T}^{1}$. Let $\widetilde{C_{T}}, \widetilde{B}, \widetilde{Y_{T}}, \widetilde{P_{T}^{1}}$ represent changes (in percentage terms) in these variables relative to the benchmark steady state, such that

$$
\widetilde{C_{T}}=r \widetilde{\widetilde{B}}+\widetilde{Y_{T}}+\widetilde{P_{T}^{1}}
$$

where the benchmark steady state provides a frame of reference and

$$
\left\{\begin{array}{c}
\tilde{X}=\frac{1}{X^{*}}\left(X-X^{*}\right), \quad \tilde{X}=\left[\widetilde{C_{T}}, \widetilde{Y_{T}}, \widetilde{P_{T}^{1}}\right] \\
\widetilde{B} \equiv \frac{d B}{C_{0}}, C_{0}=Y_{0}
\end{array}\right.
$$

where $X^{*}$ represents the benchmark steady state of $X$. It should be noted that $\widetilde{B}$ is as defined because the benchmark steady state of $B$ is assumed to be zero. As our empirical analysis will show, it does not enter the empirical model in logarithm. Moreover, net foreign assets can take negative values, making it undefined in logarithmic terms.

In the above specification, three factors drive steady-state consumption of tradables - net foreign assets, level of tradable output endowment, and terms of trade. To obtain steady state variations in production and consumption of nontradables, we linearize equations in 2.10 in the neighbourhood of the benchmark steady state defined in 2.12. This yields

$$
\left\{\begin{aligned}
\widetilde{Y_{N}} & =\widetilde{C_{N}}=\widetilde{C_{T}}-\rho \widetilde{P_{N}} \\
\widetilde{Y_{N}} & =\widetilde{C_{N}}=\frac{\mu(\sigma-\rho)}{1+\sigma \varphi} \widetilde{P_{N}}
\end{aligned}\right.
$$

The first equation in 2.15 is obtained via direct linearization of the second equation in 2.10. The second equation of 2.15 follows from linearization of $Y_{N t}$ in the last equation in 2.10, linearization of consumption index $C_{t}$ and finally by substituting the expression for $\widetilde{C_{T}}$ from the first equation of 2.15 into the linearized consumption index ${ }^{9}$. Combining the two equations in 2.15 together with 2.13 , we obtain an expression for the percentage change in the relative price of nontradables in relation to its benchmark steady state as

$$
\widetilde{P_{N}}=\frac{1+\sigma}{\rho(1-\mu)+\sigma(\mu+\rho \varphi)} \widetilde{C_{T}}=\frac{1+\sigma}{\rho(1-\mu)+\sigma(\mu+\rho \varphi)}\left(r \widetilde{B}+\widetilde{Y_{T}}+\widetilde{P_{T}^{1}}\right)
$$

\footnotetext{
${ }^{9}$ Linearization of $Y_{N t}$ around benchmark steady state yields $\widetilde{Y_{N}}=-\frac{1}{\sigma \varphi} \tilde{C}+\frac{\mu}{\varphi} \widetilde{P_{N}}$. Linearization of the consumption index around the benchmark steady state yields $\tilde{C}=\mu \tilde{C}_{T}+(1-\mu) \tilde{C}_{N}$, where $\widetilde{C_{T}}=$ $\widetilde{C_{N}}+\rho \widetilde{P_{N}}$
} 
We next derive the log-level equation that gave rise to 2.16. To achieve this, we use Taylor approximation (in reverse format) around the benchmark steady state. This yields

$$
\begin{gathered}
\log P_{N}^{*}+\frac{1}{P_{N}^{*}}\left(P_{N}-P_{N}^{*}\right)=\log \Omega+\psi r \frac{d B}{Y_{0}} \\
+\psi\left(\log Y_{T}^{*}+\frac{1}{Y_{T}^{*}}\left(Y_{T}-Y_{T}^{*}\right)+\log P_{T}^{1^{*}}+\frac{1}{P_{T}^{1^{*}}}\left(P_{T}^{1}-P_{T}^{{ }^{*}}\right)\right)
\end{gathered}
$$

or

$$
\log P_{N}=\log \Omega+\frac{\psi r}{\mu} \frac{B}{Y_{0}}+\psi \log Y_{T}+\psi \log P_{T}^{1}
$$

where $\Omega$ is a constant, $\psi=\frac{1+\sigma}{\rho(1-\mu)+\sigma(\mu+\rho \varphi)}, d B=\frac{B}{\mu}$ and $C_{0}=Y_{0}$. Equation (2.17) illustrates important implications. The right hand side of the equation suggests that the relative price of nontradables is increasing in the level of net foreign assets, tradable output, and terms of trade. Together with previous equations, equation (2.17) suggests that factors which raise the consumption of tradables generate a positive wealth effect that reduces labour supply to the nontradable sector. As production in the nontraded sector is linear in labour supply, this cuts production of nontradable goods, pushing up the relative price of nontradable goods, with an attendant appreciation of the real exchange rate.

Lastly, we derive the variation in real exchange rate. To do this, we linearize (2.3) and (2.5) and obtain

$$
\widetilde{R E R}=\tilde{P}=(1-\mu) \widetilde{P_{N}}
$$

which, in log levels as in (2.17), yields

$$
\begin{aligned}
\log (R E R)=(1-\mu) \log P_{N}=(1 & -\mu) \log \Omega+(1-\mu) \frac{\psi r}{\mu} \frac{B}{Y_{0}}+(1-\mu) \psi \log P_{T}^{1} \\
& +(1-\mu) \psi \log Y_{T} \\
= & \delta_{0}+\delta_{1} \frac{B}{Y_{0}}+\delta_{2} \log Y_{T}+\delta_{3} \log P_{T}^{1}
\end{aligned}
$$

where $\delta_{1}, \delta_{2}, \delta_{3}>0$. Equation (2.18) shows that variations in relative price of nontradables are scaled to give variations in real exchange rate. Thus, the real exchange rate is a monotonic transformation of the relative price of nontradables, so the relative price of nontradables serves 
as the mechanism linking the real exchange rate to its determinants. We use equation (2.19) as the basis for the empirical analysis presented in the subsequent sections.

\subsection{Openness and the Transfer Effect}

How does the degree of openness to international trade alter the magnitude of the transfer effect and influence the impact of net foreign assets on real exchange rates? In this section, we examine the theoretical impact that variations in openness could potentially have on 1) the magnitude of the transfer effect and 2) the magnitude of the coefficients of the other real exchange rates determinants highlighted in the benchmark model. To achieve this, we examine how each of these coefficients responds to changes in the relative size $\mu$ of the traded sector, a proxy for openness.

From equations (2.17) - (2.19), we know that the factors which drive steady-state relative price of nontradables and real exchange rates are net foreign assets, tradable output, and terms of trade. Thus, these variables each has two coefficients - one in the log relative price of nontradables equation, i.e. equation (2.17), and the other in the log real exchange rates equation, i.e. equation (2.19). To determine the effect of openness on the impact of these variables on real exchange rates, we check how the variables' coefficients behave with respect to changes in $\mu$. We do this for both equations (2.17) and (2.19).

From (2.17), the coefficient on net foreign assets $B$, can be written as

$$
C_{1_{B}}=\frac{\psi r}{\mu}=\frac{r}{\mu} \frac{1+\sigma}{[(1-\mu) \rho+(\varphi \rho+\mu) \sigma]}=\frac{r(1+\sigma)}{\mu[(\sigma-\rho) \mu+(1+\varphi \sigma) \rho]}
$$

where $\mu$ measures the relative size of the traded sector and hence the extent of openness of an economy. To determine how trade openness alters the impact of $B$ on the real exchange rate, we deduce the sensitivity of $C_{1_{B}}$ to $\mu$. As the relative size of the traded sector $\mu$ captures the extent of openness to trade, a high $\mu$ implies high openness and vice versa. Meanwhile, the coefficient $C_{1_{B}}$ on net foreign assets $B$ captures the magnitude of the transfer effect for a given $\mu$. Thus, the sensitivity of $C_{1_{B}}$ to $\mu$ indicates how the transfer effect is altered when openness changes and this is obtained by differentiating $C_{1_{B}}$ with respect to $\mu$ as follows

$$
\frac{\partial C_{1_{B}}}{\partial \mu}=-\frac{2 \mu(\sigma-\rho)+(1+\varphi \sigma) \rho}{\mu^{2}[(\sigma-\rho) \mu+(1+\varphi \sigma) \rho]^{2}}
$$

and 




From (2.19), the coefficient of net foreign assets, representing the magnitude of the transfer effect, is

$$
C_{2_{B}}=(1-\mu) \frac{\psi r}{\mu}=(1-\mu) C_{1_{B}}
$$

As in the preceding case, sensitivity of $C_{2_{B}}$ to $\mu$ is determined as follows

$$
\begin{aligned}
\frac{\partial C_{2_{B}}}{\partial \mu} & =(1-\mu) \frac{\partial C_{1_{B}}}{\partial \mu}-C_{1_{B}} \\
=- & (1-\mu) \frac{2 \mu(\sigma-\rho)+(1+\varphi \sigma) \rho}{\mu^{2}[(\sigma-\rho) \mu+(1+\varphi \sigma) \rho]^{2}}-\frac{r(1+\varphi \sigma)}{\mu[(\sigma-\rho) \mu+(1+\varphi \sigma) \rho]} \\
= & -(1-\mu) \frac{2 \mu(\sigma-\rho)+(1+\varphi \sigma) \rho}{\mu^{2}[(\sigma-\rho) \mu+(1+\varphi \sigma) \rho]^{2}}-\frac{r^{2}(1+\varphi \sigma)^{2}}{\mu^{2}[(\sigma-\rho) \mu+(1+\varphi \sigma) \rho]^{2}} \\
& =-\frac{(1-\mu)}{\mu^{2}[(\sigma-\rho) \mu+(1+\varphi \sigma) \rho]^{2}}[2 \mu(\sigma-\rho)+(1+\sigma) \rho \\
& \left.+\frac{r^{2}(1+\varphi \sigma)^{2}}{(1-\mu)}\right]
\end{aligned}
$$

Thus,

$$
\begin{aligned}
& \frac{\partial C_{2_{B}}}{\partial \mu} \\
& =\left\{\begin{array}{c}
-\frac{(1-\mu)}{\mu^{2}[(\sigma-\rho) \mu+(1+\varphi \sigma) \rho]^{2}}\left[2 \mu(\sigma-\rho)+(1+\varphi \sigma) \rho+\frac{r^{2}(1+\varphi \sigma)^{2}}{(1-\mu)}\right]<0, \quad \sigma>\rho \\
-\frac{(1-\mu)}{\mu^{2}[(\sigma-\rho) \mu+(1+\varphi \sigma) \rho]^{2}}\left[2 \mu(\sigma-\rho)+(1+\varphi \sigma) \rho+\frac{r^{2}(1+\varphi \sigma)^{2}}{(1-\mu)}\right]><0 \quad \sigma<\rho
\end{array}\right.
\end{aligned}
$$


The results of the sensitivity analysis in (2.22) and (2.25) suggest a smaller effect of net foreign assets on real exchange rates as openness increases if $\sigma>\rho$ and a possibly larger effect as openness increases if $\sigma<\rho$. That is, high openness decreases the impact of net foreign assets on real exchange rates when the intertemporal elasticity of substitution dominates the intratemporal elasticity of substitution. On the other hand, high openness could possibly increase the size of the transfer effect when the intratemporal elasticity of substitution dominates the intertemporal elasticity of substitution. Thus, the intertemporal and intratemporal elasticities of substitution are two central parameters that determine the sensitivity of the relationship between net foreign assets and real exchange rates to openness.

As the theoretical model suggests, there is some congruency in behaviour, at least in theory, in the coefficients of terms of trade and relative per capita output. Let $C_{1}{ }_{V}$ represent the common coefficient of terms of trade and relative per capita output in (2.17) and $C_{2_{V}}$ represent the common coefficient of terms of trade and relative per capita output in (2.19). From (2.17) and (2.19), coefficients $C_{1_{V}}$ and $C_{2_{V}}$ can be written as

$$
\left\{\begin{array}{l}
C_{1_{V}}=\frac{1+\sigma}{\rho(1-\mu)+\sigma(\mu+\rho \varphi)} \\
C_{2_{V}}=\frac{(1-\mu)(1+\sigma)}{\rho(1-\mu)+\sigma(\mu+\rho \varphi)}
\end{array}\right.
$$

and the sensitivity of $C_{1_{V}}$ and $C_{2_{V}}$ to $\mu$ is determined as follows

$$
\begin{aligned}
& \frac{\partial C_{1_{V}}}{\partial \mu}= \begin{cases}-\frac{(\sigma-\rho)(1+\sigma)}{[(\sigma-\rho) \mu+(1+\varphi \sigma) \rho]^{2}}<0, & \sigma>\rho \\
-\frac{(\sigma-\rho)(1+\sigma)}{[(\sigma-\rho) \mu+(1+\varphi \sigma) \rho]^{2}}>0 & \sigma<\rho\end{cases} \\
& \frac{\partial C_{2_{V}}}{\partial \mu}=-\frac{\sigma(1+\sigma)(1+\varphi \sigma)}{[(\sigma-\rho) \mu+(1+\varphi \sigma) \rho]^{2}}<0 \quad \forall \sigma, \rho>0
\end{aligned}
$$

The results for the sensitivity analysis of the variables are presented in (2.26) and (2.27). For the sensitivity analysis of the real exchange rates equation, i.e. (2.27), the result suggests that for all plausible values of the intertemporal and intratemporal elasticity of substitution, the impact of terms of trade and relative per capita output on real exchange rates, no matter the magnitude of the impact, will eventually diminish as openness increases. Meanwhile, for the sensitivity analysis of relative price of nontradables equation, i.e. (2.26), it is seen that there is a decreasing effect as openness increases if $\sigma>\rho$ and this is similar to the result obtained in 
the preceding sensitivity analysis for the impact of net foreign assets on relative price of nontradables as in (2.22) for $\sigma>\rho$. However, in the case where $\sigma<\rho$, the model suggests a larger impact of terms of trade and relative per capita output on the relative price of nontradables as openness increases, i.e. an increase in openness enlarges the impact of terms of trade and relative output on the relative price of nontradables if $\sigma<\rho$-if intertemporal elasticity of substitution is below the intratemporal elasticity of substitution.

\subsection{Data and Empirical Analysis}

\subsubsection{Data}

This section describes the data samples used in the empirical analysis, specifically the measures of real exchange rates, net foreign assets, relative per capita income, and terms of trade. Our sample includes SSA countries selected based on the availability of data. The data samples for the analysis come from multiple sources which are - The World Bank, IMF, Lane and MilesiFerretti $(2001,2004,2007)$ and Darvas $(2012,2016)$. The data samples for net foreign assets come from Lane and Milesi-Ferretti $(2001,2004)$ and the updated and extended version of Lane and Milesi-Ferretti (2007) which is a newly constructed dataset on countries' net external positions. We draw data from diverse sources as no one source provides data for a considerable number of SSA countries for an extended period. The way in which the datasets for net foreign assets are defined and constructed are in Lane and Milesi-Ferretti (2001, 2004).

Most studies on Balassa-Samuelson hypothesis use total factor or labour productivity differentials between traded and nontraded sectors to explain the dynamics of real exchange rates. However, data samples on sectoral output, total factor productivity or labour productivity differentials are unavailable for a broad range of developing countries, most especially SSA. Thus, we draw on Lane and Milesi-Ferretti (2004) and proxy productivity differentials with relative per capita output. The relative per capita output is based on per capita output levels in dollars, sourced from World Bank, and is defined as the per capita output level of each SSA country $i$ relative to its major trading partners. Lastly, terms of trade are computed as ratio of export prices to import prices, where export and import prices are expressed in dollars; dates for financial liberalization come from countries' recent and official news fillings and from sources such as Reinhart and Tokatlidis (2000), Seek and El Nil (1993), Fowowe (2008).

\subsubsection{Empirical Analysis}

The empirical analysis presented in this paper is in two parts. In the first part, we directly analyse the implications of the theoretical model, with a focus on countries' net foreign assets 
position and the transfer problem. In the second part, we extend the empirical analysis to include financial liberalization as a possible determinant of real exchange rates behaviour in SSA and we test the validity of such hypothesis. We begin now with the first part. In this part, we examine two dimensions of the data: cross-sectional and panel specifications. As is standard in the empirical literature, we begin the first part of our analysis with the cross-sectional specification, which is the first step in our quest to examine all dimensions of our data. Findings from our empirical analysis would not be based solely on cross-sectional analysis. One benefit of considering cross-sectional correlations is that they provide preliminary insight into the existence and extent of empirical issues such multicollinearity among variables across countries. Any loss of information due to considering differences of variables is made up for in the panel analysis presented subsequently.

\subsubsection{Cross-sectional Empirical Specification}

Following Lane and Milesi-Ferretti (2004), we specify the cross-sectional regression model as follows

$$
\begin{gathered}
R E R_{i, t T}-R E R_{i, s t}=\alpha+\beta_{1}\left(N F A_{i, t T}-N F A_{i, s t}\right)+ \\
\beta_{2}\left(R E L_{i, t T}-R E L_{i, s t}\right)+\beta_{3}\left(T T_{i, t T}-T T_{i, s t}\right)+\varepsilon_{i},
\end{gathered}
$$

where $s t$ and $t T$ denote average values over the closed intervals $[s, t]$ and $[t, T]$. In this crosssectional specification, we use differences on differences rather than levels, the reason being that levels are not directly comparable across countries because real exchange rates and terms of trade are index-based. Moreover, differences of period averages, rather than end year averages, are used because of the tendency of real exchange rates to deviate from fundamental values in the short term.

As a starting exercise, we address whether changes in average real exchange rates across countries are correlated with changes in net foreign assets, relative GDP per capita and terms of trade. To do this, we first calculate mean values of each variable for the periods 1980 - 1995 and 1996-2011 and then take the difference of both means. This yields the variables that enter our cross-sectional analysis. Below, we present the bivariate correlations between changes in average real exchange rates, net foreign assets, relative GDP per capita and terms of trade, and we also present the multivariate regression analysis.

\subsubsection{Bivariate Correlations}

We present below the bivariate correlations between changes in average real exchange rates $\triangle R E R$, relative GDP per capita $\triangle R E L$, net foreign assets $\triangle N F A$ and terms of trade $\triangle T T$. 
IBHAGUI Transfer Problem in Sub-Saharan Africa

Table 2.0a - Cross Sectional Correlations - Sub-Saharan Africa

\begin{tabular}{|l|c|c|c|c|}
\hline & $\Delta R E R$ & $\Delta$ NFA & $\Delta R E L$ & $\Delta T T$ \\
\hline$\Delta R E R$ & 1.00 & & & \\
\hline$\Delta$ NFA & 0.18 & 1.00 & & \\
\hline$\Delta$ REL & 0.27 & 0.33 & 1.00 & \\
\hline$\Delta$ TT & 0.10 & 0.15 & 0.38 & 1.00 \\
\hline
\end{tabular}

Notes: Cross sectional correlation estimates for countries in sub-Saharan Africa are computed using data samples of real exchange rates, net foreign assets, relative income and terms of trade from the sources described in the previous section. The data samples for the observations are all drawn from sub-Saharan Africa.

Table 2.0a lists bivariate correlations between changes in average real exchange rates ( $\triangle \mathrm{RER}$ ) and changes in average NFA to GDP ratio $(\triangle \mathrm{NFA})$, relative GDP per capita $(\triangle \mathrm{REL})$ and the terms of trade $(\triangle \mathrm{TT}) . \Delta \mathrm{RER}$ and $\triangle \mathrm{NFA}$ are positively correlated for SSA countries, providing a very preliminary confirmation of the predictions of the theoretical model. However, the correlation coefficient is rather weak, implying that a positive but weak association exists between $\triangle R E R$ and $\triangle N F A$. This result agrees with Lane and Milesi-Ferretti (2004) who also find a weak correlation between the two variables for the broader developing countries. The weak positive correlation suggests that the transfer effect in SSA, if it occurs, is likely to have a relatively low magnitude. The correlation result also shows that $\triangle R E R$ bears a low and positive correlation with $\triangle R E L$, in line with previous studies which find that $\triangle R E R$ and $\triangle R E L$ are weakly correlated in developing countries, possibly signifying a weak evidence of the Balassa-Samuelson hypothesis.

The correlation between $\triangle R E R$ and $\triangle T T$, though positive, is even lower, the weakest of all, suggesting that changes in terms of trade have very little positive association with changes in real exchange rates. In contrast, $\triangle T T$ has a strong and positive correlation with $\triangle R E L$. Furthermore, $\triangle T T$ is positively correlated with $\triangle N F A$, while $\triangle N F A$ and $\triangle R E L$ are strongly and positively correlated. This strong and positive correlation between $\triangle N F A$ and $\triangle R E L$ suggests that changes in net foreign assets are in lockstep with relative productivity growth. As a direct interpretation of the result, for instance, SSA countries with accelerated growth patterns compared to their trading partners also see significant improvements in net foreign assets. The six correlations, which are well-depicted graphically in Fig.2, are compared with those obtained for developing and industrial countries in the literature (in Table 2b). Overall, compared to developing and industrial countries, correlation coefficients between the variable pairs for SSA countries are generally smaller. Notwithstanding, the correlation coefficients all point to a positive association, although of varying strength, between the six variable pairs. 
Figure 2.0: Real exchange rates, net foreign assets, relative GDP per capita and terms of trade - Cross-sectional Correlations
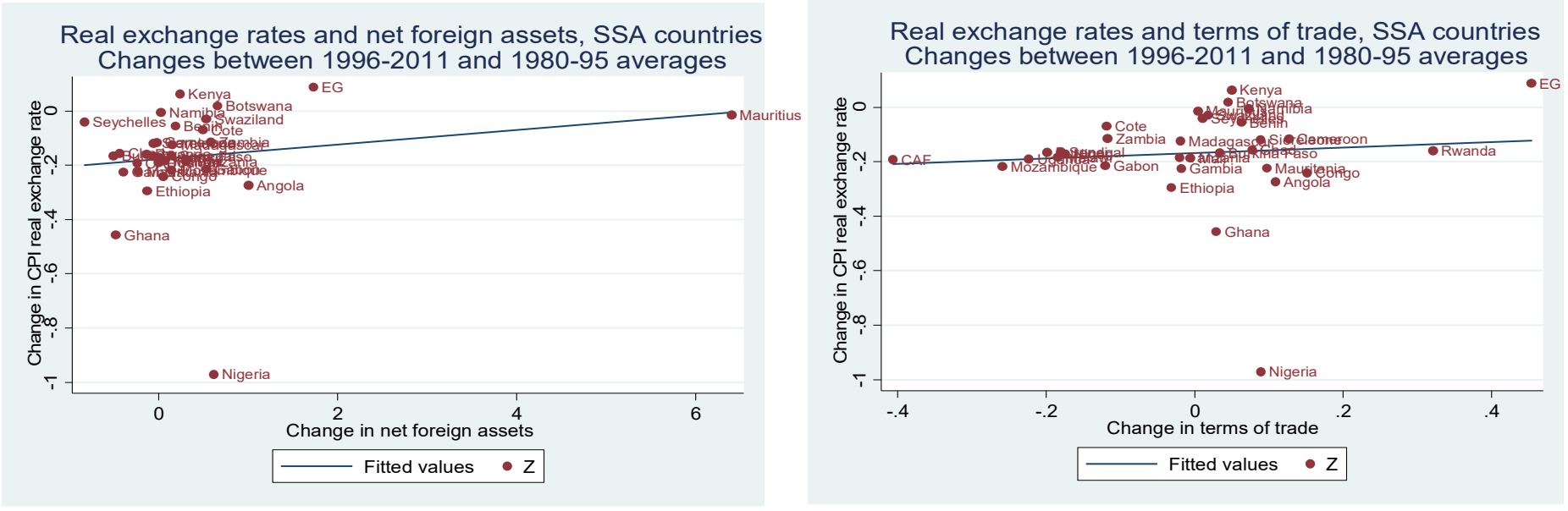

Real exchange rates and relative GDP per capita, SSA countries Changes between 1996-2011 and 1980-95 averages

Net foreign assets and Relative GDP per capita, SSA countries

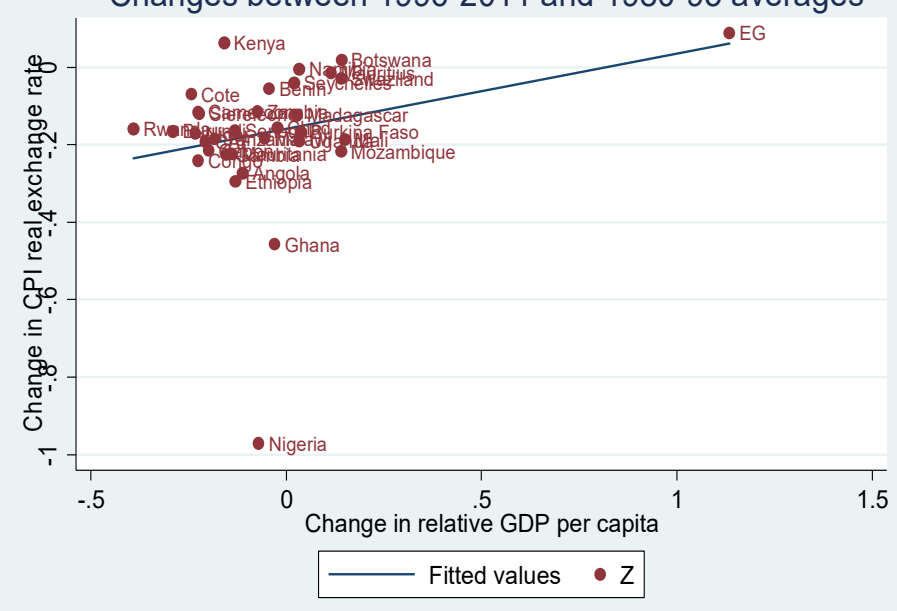

Changes between 1996-2011 and 1980-95 averages



Net foreign assets and terms of trade, SSA countries Changes between 1996-2011 and 1980-95 averages

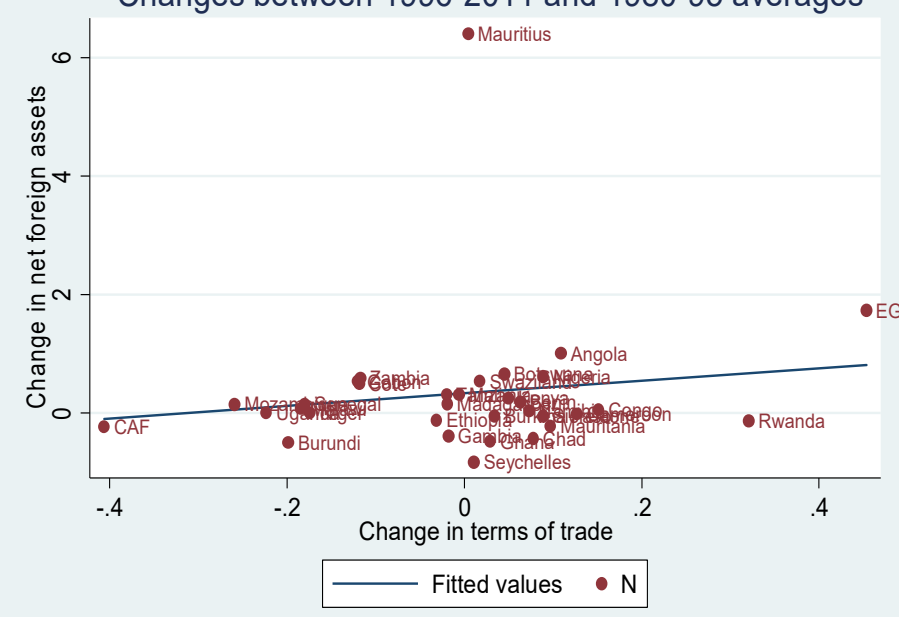

Relative GDP per capita and terms of trade, SSA countries




IBHAGUI Transfer Problem in Sub-Saharan Africa

Table 2.0b - Comparison of Cross-Sectional Correlations

\begin{tabular}{|c|c|c|c|}
\hline & SSA & Developing Countries & Industrial Countries \\
\hline (DRER, $\triangle N F A)$ & 0.18 & 0.40 & 0.48 \\
\hline$(\triangle R E R, \triangle R E L)$ & 0.27 & 0.17 & 0.45 \\
\hline$(\triangle R E R, \Delta T T)$ & 0.09 & 0.30 & 0.56 \\
\hline$(\triangle N F A, \Delta T T)$ & 0.15 & 0.55 & 0.12 \\
\hline$(\triangle N F A, \triangle R E L)$ & 0.33 & 0.49 & 0.76 \\
\hline$(\Delta T T, \Delta R E L)$ & 0.38 & 0.57 & 0.14 \\
\hline
\end{tabular}

Notes: Cross sectional correlation estimates for countries in sub-Saharan Africa are computed using data samples of real exchange rates, net foreign assets, relative income and terms of trade from the sources described in the previous section. The cross-sectional correlations for developing and industrial countries are obtained from Lane and MilesiFerretti (2004) as that is the only comprehensive study to date where such cross-sectional correlation analyses are performed for different countries.

\subsubsection{Cross-sectional Multivariate Regression}

We turn now to results from multivariate cross-country regression analysis based on the empirical specification presented in equation (2.28). As argued in the introduction, terms of trade is an important exogenous component for SSA countries because these countries are involved in vast amounts of international trade in which prices are exogenously determined. Finally, we include relative output per capita to eliminate any indirect effects of net foreign assets on real exchange rates emanating from their impact on the growth performance of relative output per capita. The results obtained are presented in Table 2.1 below. We report results from the regression using changes in CPI-based real exchange rates $\triangle R E R$ as dependent variable and $\triangle N F A$ as our explanatory variable of interest.

The results in Table 2.1, which report regressions using changes in the CPI-based real exchange rates as the dependent variable, present step-by-step findings obtained by a) excluding from the list of explanatory variables one of $\triangle T T, \triangle R E L$ and $\triangle N F A$ (as in columns (1), (2), and (3) respectively) and b) including all explanatory variables $\triangle T T, \triangle R E L$ and $\triangle N F A$ as regressors (as in column (4)). The aim of this exercise is to ascertain how the magnitude of the transfer effect and impact of other explanatory variables on real exchange rates in the crosssectional analysis may be altered when the correlation between $\triangle T T$ and $\triangle R E L$ is taken into consideration. As a final note, we include results when the three explanatory variables $\Delta T T$, $\triangle R E L$ and $\triangle N F A$ are simultaneously present. 
Table 2.1: Real Exchange Rates Determinants (Change Between Averages For 19801995 And 1996 - 2011)

\begin{tabular}{|c|c|c|c|c|}
\hline & $(1)$ & $(2)$ & $(3)$ & $(4)$ \\
\cline { 2 - 5 } & Exclude $\Delta T T$ & Exclude $\triangle R E L$ & Exclude $\Delta N F A$ & Include All \\
\hline$\Delta N F A$ & $0.03^{*}$ & $0.03^{*}$ & - & $0.02^{* *}$ \\
\hline & $(2.02)$ & $(2.09)$ & - & $(2.59)$ \\
\hline$\Delta R E L$ & $0.24^{* * *}$ & - & 0.70 & 0.60 \\
\hline & $(3.61)$ & - & $(1.03)$ & $(1.72)$ \\
\hline$\Delta T T$ & - & 0.33 & -1.20 & -0.96 \\
\hline Adj. $\boldsymbol{R}^{2}$ & - & $(1.46)$ & $(0.71)$ & $(1.26)$ \\
& 0.30 & 0.19 & 0.34 & 0.40 \\
\hline Observations & 33 & 33 & 33 & 33 \\
& & & & \\
\hline
\end{tabular}

Notes: In columns (1)-(4), the test statistic associated with each variable is in parenthesis. The estimates in the first three columns are included as a form of robustness checks to see how the results are affected by the independent variables that are correlated. Including both $\triangle T T$ and $\triangle R E L$ in a regression dilutes the significance of each of them. When both are not included simultaneously, at least one of them turns out significance. This is not surprising because the highest correlated recorded in our correlation analysis is exactly that between both variables.. *, $* *$ and $* * *$ indicate statistical significance at $10 \%, 5 \%$ and $1 \%$ significance level, respectively, as $* \mathrm{p}<.1 ; * * \mathrm{p}<.05 ; * * * \mathrm{p}<.01$.

In the instances where $\triangle N F A$ is included in the regression (see columns (1), (2) and (4)), we find that the transfer effect is unaltered - changes in net foreign assets are found to have a positive and significant impact on changes in real exchange rates in SSA. However, the results for the other hypothesized determinants of real exchange rates are not as robust. Indeed, when both $\triangle T T$ and $\triangle R E L$ are included in the regression (columns (3) and (4)), we find that neither of them is significant, but when either of them is included (as in column (1)), the result suggests that changes in relative per capita GDP $\triangle R E L$ positively impacts changes in real exchange rates $\triangle R E R$ and the relationship is significant. As for $\triangle T T$, the results suggest that in none of the regressions is it significant, even when $\triangle R E L$ is excluded (column (2)). When no discrimination is made and all explanatory variables are included in the regression (column (4)), we find that the positive and significant relationship between $\triangle N F A$ and $\triangle R E R$ survives, while $\triangle R E L$, though retains its positive relationship with $\triangle R E R$, loses its significance. The relationship between $\triangle T T$ and $\triangle R E R$ remains insignificant and surprisingly becomes negative, perhaps confirming the weak positive correlation between both variables earlier obtained in the correlation analysis. 
As previously mentioned, we consider terms of trade as an exogenous determinant of real exchange rates, especially for small open economies such as SSA countries, and thus include them in our regressions as a control variable. We find that the transfer effect holds as changes in net foreign assets continue to bear a positive relationship with changes in real exchange rates. The rationale for controlling for terms of trade is that any evidence of a transfer effect must operate via the relative price of nontradables. We also control for relative output per capita so that it does not generate a relative output growth performance that serves as a mechanism or conduit linking the indirect effects of net foreign assets on real exchanges rates. Furthering our sensitivity analysis, we reanalyze the relationship by omitting terms of trade as well as relative output per capita, one after the other. Interestingly, we find that omitting the terms of trade or relative output per capita does not alter the economic and statistical significance of the link between real exchange rates and net foreign assets in SSA.

On the whole, we conclude that changes in CPI-based real exchange rates are positively related to changes in net foreign assets in all instances, positively related to changes in relative output per capita in one instance but, somewhat surprisingly, unrelated to changes in terms of trade in all instances. Excluding changes in either net foreign assets or relative output per capita over the sample period does not seem to alter this finding substantially. The result agrees with some previous studies ${ }^{10}$ that surprisingly find that changes in terms of trade do not have a statistically and economically significant impact on real exchange rates changes in developing countries. Meanwhile, the correlation between changes in terms of trade and changes in relative GDP per capita perhaps partly explains why the positive correlations of these variables with changes in real exchange rates do not fully survive in a multivariate regression. Overall, the cross-sectional analysis presented in this section resoundingly suggests some evidence of a transfer problem in SSA.

Despite their convenience, we note that cross-sectional analysis is constrained with respect to sample size, is unable to analyze patterns over a period of time and can be fraught with empirical issues inclusive of lower degrees of freedom that potentially limits estimation power and efficiency, especially for developing countries with rapidly changing macroeconomic fortunes over time, and thus may not adequately capture the patterns that are of interest to us due to, for instance, ignoring the presence of potential unobserved heterogeneity. Furthermore, Lane and Milesi-Feretti (2004) find that the overall fit for cross sectional regression is weak. In light of these limitations, we turn now to a panel empirical analysis which is more elaborate and blends inter-country differences and intra-country dynamics, creating a greater capacity to

\footnotetext{
${ }^{10}$ Lane and Milesi-Ferreti (2004) find that terms of trade have a statistically and economically significant impact on the real exchange rate in industrial countries; however, somewhat surprisingly, not in developing countries and excluding countries with large changes in the black-market premium over their sample does not alter this finding substantially.
} 
capture the complexity of the behavior of variables across countries than can be achieved with cross-sectional analysis, Hsiao (2007) ${ }^{11}$.

\subsection{Panel Empirical Specification}

In this section, we extend our investigation of real exchange rates determinants and perform a panel empirical analysis. As in the previous section, the empirical specification for the panel analysis follows from the testable theoretical model presented in (2.19). Accordingly, the panel specification, estimated in each regression as a dynamic panel estimation, where the dynamic term is the one-period lagged dependent variable, is given by

$$
R E R_{i t}=\alpha_{i}+\beta_{1} N F A_{i t}+\beta_{2} T T_{i t}+\beta_{3} R E L_{i t}+\varepsilon_{i t}
$$

where $R E R$ is the real effective exchange rates $^{12}, \alpha_{i}$ is the country-specific fixed effect, $N F A, T T$ and REL measure the net foreign assets position, terms of trade and relative output per capita, respectively, and $\varepsilon_{i t}$ is the idiosyncratic error term. Unlike real exchange rates, terms of trade and relative output per capita, it is important to note that net foreign assets are not expressed in logarithm in order to accurately specify the panel regression in line with the theory model in (2.19) and as is standard in the literature. Consequently, $\beta_{2}$ and $\beta_{3}$ denote terms of trade and relative output per capita elasticities of real exchange rates, while $\beta_{1}$ denotes semi elasticity of net foreign assets with respect to real exchange rates. The expected signs of the elasticities are $\beta_{1}>0, \beta_{2}>0$ and $\beta_{3}>0$. Baxter (1994) argues that at lower frequencies, a positive relationship exists between real exchange rates and real interest rates differentials, so that real interest rates differentials possibly play a role in determining real exchange rates. Accordingly, we empirically augment the base model in (2.29) to include real interest rates differentials as a potential real exchange rates determinant. This yields (2.30) below, which enables us to observe variations in behavior and significance of the variables hypothesized as real exchange rates determinants.

$$
R E R_{i t}=\alpha_{i}+\beta_{1} N F A_{i t}+\beta_{2} T T_{i t}+\beta_{3} R E L_{i t}+\beta_{4} R I R D_{i t}+\varepsilon_{i t}
$$

\footnotetext{
${ }^{11}$ Hsiao (2007) reports that 'Advantages of panel data over time series data or cross-section data is more degrees of freedom, less multicollinearity, and more variation in the data that results in more efficiency of the estimators. In addition, panel data allows us to control for heterogeneity, study dynamics, and test more complicated behavioural hypotheses than is possible with a single time series or cross-section. Panel data generate better predictions and provide micro-foundations for aggregate data analysis....

${ }^{12}$ We use real effective exchange rates and real exchange rates interchangeably. The real exchange rates data used for the analysis is the real effective exchange rates. See the data description section
} 
To remain in line with the literature, the real interest rates differential, $R I R D_{i t}$, like net foreign assets, is not expressed in logarithm in (2.30). As a result, its coefficient, $\beta_{4}$, which is expected to be positive, $\beta_{4}>0$, is a semi-elasticity. Both regression specifications in (2.29) and (2.30) include country fixed effects which are important because variables such as real exchange rates etc. are index numbers and thus their levels are not necessarily comparable across countries. Moreover, they also account for other time-invariant, unobservable factors, country-specific effects, thus reducing the omitted variable bias and ensuring that estimated coefficients are able to consistently capture long-run variations in the data.

As stated in Lane and Milesi-Ferreti (2004), it is likely that there exists a plausible endogeneity running from real exchange rates to the regressors, for instance from real exchange rates to net foreign assets, and this might potentially affect the estimated coefficients. Accordingly, we estimate the panel models in (2.20) and (2.30) with the generalized method of moments (GMM) technique which uses appropriate instruments to address such endogeneity concerns. Another attraction of the GMM estimator is its ability to work well with unbalanced panels - and our datasets are unbalanced panels. The estimated coefficients of the variables in (2.29) and (2.30) are presented in Table 2.2a below.

Table 2.2a presents results of panel regressions for the empirical specifications in equations (2.29) and (2.30). We report the average short and long run results and diagnostic statistics based on different instruments count. One of the advantageous features of GMM is that it enables the computation of long run coefficients from short run coefficients in a dynamic panel data setting. Also, as stated in Bond (2002), even in estimations where the coefficient of the lagged dependent variable, the dynamic variable, is not of direct focus, allowing for such dynamic variable in empirical specifications is important for recovering consistent estimates of other model parameters. If the coefficient of the dynamic variable, the one-period lagged dependent variable, is $\vartheta$ then the long run coefficient of a regressor within the model, having coefficient $\omega$ in the model, is given by $\delta=\frac{\omega}{1-\vartheta}$. Meanwhile, the diagnostic statistics reported confirm that our instruments are valid and model is appropriately specified.

Moving on to the main results in Table 2.2a, we find that overall, several important features emerge. First, and most important, there is a positive and significant relationship between real exchange rates and NFA, providing evidence of a significant transfer effect in SSA. However, the magnitude of the transfer effect is quite weak given that the estimated NFA coefficient is low, ranging between 0.02-0.03. The implied interpretation of the low coefficient is as follows: a 10-percentage point growth in net foreign assets in SSA would require and implies a long-run real appreciation of 0.2 to 0.3 percent; alternatively, a 50-percentage point decline in net foreign assets implies a real depreciation of 1 to 1.5 percent - suggesting that the size of the transfer 
Table 2.2a: Real Exchange Rates, Net Foreign Assets and other Determinants: Panel Regressions

\begin{tabular}{|c|c|c|c|c|}
\hline & \multicolumn{2}{|c|}{ Difference GMM (I) } & \multicolumn{2}{|c|}{ Difference GMM (II) } \\
\hline \multirow{3}{*}{$R E R_{i t-1}$} & & $0.58 * * *$ & $0.53 * * *$ & \\
\hline & & $(36.21)$ & $(15.17)$ & \\
\hline & Short Run & Long Run & Short Run & Long Run \\
\hline \multirow[t]{2}{*}{$N F A$} & $0.01 * * *$ & $0.02 * * *$ & $0.01 * * *$ & $0.03 * * *$ \\
\hline & (3.81) & & (3.75) & \\
\hline \multirow[t]{2}{*}{$T T$} & $0.01 * *$ & $0.04 * * *$ & $0.04 * * *$ & $0.09 * * *$ \\
\hline & $(2.21)$ & & (2.77) & \\
\hline \multirow[t]{2}{*}{$R E L$} & $0.09 * * *$ & $0.23 * * *$ & $0.08 * * *$ & $0.16^{* * *}$ \\
\hline & $(5.46)$ & & $(3.41)$ & \\
\hline \multirow[t]{2}{*}{ RIRD } & - & - & $0.0004 * * *$ & $0.001 * * *$ \\
\hline & - & - & $(3.23)$ & \\
\hline \multicolumn{5}{|c|}{ Diagnostic Tests } \\
\hline Observations & 1,068 & & 1,006 & \\
\hline Instruments & 153 & & 117 & \\
\hline Wald Test & {$[0.000]$} & & {$[0.000]$} & \\
\hline $\begin{array}{l}\text { Arellano-Bond } \\
\text { Test ( } p \text {-value) }\end{array}$ & 0.1877 & & 0.1680 & \\
\hline Sargan Test & {$[0.6582]$} & & [0.9999] & \\
\hline
\end{tabular}

Notes: Dependent variable is the $\log$ of CPI based RER, ***,**,* denote statistical significance at the $1 \%, 5 \%$, and $10 \%$ levels, respectively.

The figures in parenthesis ( ) are modulus $\mathrm{z}$ ratios while figures in brackets [ ] are pvalues. P-values more than 0.10 indicates non-rejection of the null. Arellano-Bond Test is the serial correlation/autocorrelation test of Arellano and Bond and Sargan Test is the test of over identifying restriction proposed by Sargan. Estimation by difference generalized method of moments' estimation technique, model is well specified, over identifying restrictions are satisfied and instruments are valid.

effect is low in $\mathrm{SSA}^{13}$. The results also propose that terms of trade and relative output per capita improvements are associated with real exchange rates appreciation and this contrasts with

\footnotetext{
${ }^{13}$ This turns out advantageous for SSA. Indeed, many SSA countries suffer from dollarization and have a significant component of their external liabilities/debts denominated in foreign currencies. Excessive real exchange rates depreciation is not very welcome because it has the potential to elevate the size of the external liabilities in domestic terms and consequently debt-burden these countries. The consequences of such outcome are far-reaching, and can include depressed growth and debt crises, among others, which proceeds from the resulting exports on the back of depreciated real exchange rates
} 
earlier cross-sectional analysis and some previous studies such as Lane and Milesi-Ferretti (2004) that find no clear relation between real exchanges rates and terms of trade for developing countries. With respect to earlier studies, our results suggest that such a lack of evidence might be attributable to the characteristics of the developing countries included in the samples analyzed in the past studies. Meanwhile, the magnitudes of long-run real appreciations for terms of trade and relative output per capita, particularly for relative output per capita, are several times that of NFA. They are statistically significant and have reasonable economic significance. For terms of trade, the long-run coefficient, though above the coefficient of net foreign assets, is below that of relative per capita output and could explain why SSA countries have recorded only minor real appreciation despite running healthy terms of trade. It also provides insights on how several SSA countries have been able to maintain a not-so-depreciated level of real exchange rates despite having weak or sometimes deteriorating levels of terms of trade, and this possibly explains why these countries can still afford to import essential units of capital and consumer goods while some can afford to be import dependent.

As a robustness check, and to test the hypothesis that increases in real interest rates differentials appreciate real exchange rates in SSA, we estimate the extended panel specification that includes real interest rates differentials, where the world real interest rate is taken as that of the US and the real interest rates differential is the real interest rate of each SSA country less the world real interest rate. The result, presented in the second column of Table 2.2a, continues to show that the initial findings remain unaltered. In particular, we continue to find evidence supportive of a significant transfer effect in SSA, though the size of the transfer effect remains low. The result also confirms that the hypothesis that real interest rates differential appreciates real exchange rates, is true in SSA. Thus, as a by-product, our result confirms Baxter (1994) findings that real interest rates differentials relate positively with real exchange rates for low-frequency samples, but our estimated coefficient, though positive and significant, is infinitesimal, making the established relationship not economically significant. This leads us to conclude that the relationship between real interest rates differential and real exchange rates does not have much economic significance in SSA. While including real interest rate differential could potentially interact with terms of trade, we note that such an inclusion is a form of robustness checks or sensitivity analysis and does not alter the finding of our main question which is to empirically investigate the existence of a transfer problem in SSA. On the whole, the estimated coefficients of net foreign assets, whether or not real interest rates differential is included, are remarkably similar and in line with those obtained in the crosssectional analysis. The results obtained from the panel empirical analysis are thus

might not be able to able to cover, especially given that the demand for these exports might not be elastic, i.e. might not be very responsive to weaker exchange rates or lower prices or both. 
consistent with those from cross-sectional analysis, particularly the evidence of the existence of a small but significant transfer effect in SSA. On average, estimated coefficients that are less significant in the cross-sectional analysis become more significant in the panel analysis while those not significant become significant.

Below we compare our results to those obtained in previous studies for developing and industrial economies. This is shown in Table $2.2 \mathrm{~b}$. Terms of trade has the same effect on real exchange rates in SSA as it does in industrial and large sample economies, but the relationship is statistically insignificant only in developing countries. The magnitude of transfer effect is considerably smaller in SSA compared to the developing and industrial economies and similar to the large sample economies. It is 10 times and 6 times smaller compared to the developing and industrial economies, respectively. For relative per capita output, the coefficient is largely similar to that of developing economies but less than that of industrial and large sample economies. This suggests that the Balassa Samuelson effect, wherever it holds, is stronger in the industrial economies than in the developing economies, inclusive of SSA.

Overall, the main inference from these results, and an answer to a research question posed in this paper, is that the hypothesis of a transfer effect in SSA is supported empirically. However, compared to other economies analyzed in some previous studies (see Gagnon (1996), Lane and Milesi-Ferretti (2004) and Ricci et.al (2008) for developing, industrial and large sample economies), the magnitude of transfer effect in SSA is small. An important inference from this finding is that, like other economies, a rise in net external liabilities will eventually require a real depreciation in SSA; however, this depreciation is relatively low in SSA when compared to other economies, implying that the transfer problem is small in SSA. In this instance, a small transfer problem indicates a relatively less magnified level of external debt burden, in domestic terms, and a possibly low likelihood of default on debt.

\subsubsection{Empirical Link for Openness and the Transfer Effect}

So far, in our panel regressions, we have been implicitly silent on the influence that trade openness could have on the coefficients of the variables that explain the behavior of real exchange rates in SSA. As shown in the original benchmark model, the coefficients of NFA, the transfer effect, and other real exchange rates determinants, can change with changes in openness ${ }^{14}$. In particular, the benchmark model predicts that the transfer effect is decreasing in

\footnotetext{
${ }^{14}$ Previous studies, e.g. Lane (2002) and Lane and Milesi-Ferretti (2004) sometimes find that effects of variables particularly terms of trade on real exchange rates are not significant for developing countries. However, in this paper, we find some preliminary evidence that the effect is in fact positive and significant for SSA countries, a subset of developing countries. This suggests to us that (developing) countries might exhibit some difference or heterogeneity due to certain economic characteristics and
} 
openness so that more openness reduces the size of the transfer effect. As such, the transfer effect should be smaller, the more open is an economy. Is this empirically supported for SSA data?

To answer this question, we adopt the procedure in Lane and Milesi-Ferretti (2004) and partition the panel into three groups, with each group comprising countries with either high, medium or low openness to trade, and then we estimate the model for each group. We define

Table 2.2b: Comparison with Developing and Industrial Economies

\begin{tabular}{|c|c|c|c|c|}
\hline & (1) & (2) & (3) & (4) \\
\hline & $\begin{array}{c}\text { Sub-Saharan Africa } \\
\text { (SSA) }\end{array}$ & $\begin{array}{c}\text { Developing Economies } \\
\text { (DE) }\end{array}$ & $\begin{array}{l}\text { Industrial Economies } \\
\text { (IE) }\end{array}$ & $\begin{array}{l}\text { Large Sample } \\
\text { Economies (LS) }\end{array}$ \\
\hline \multirow[t]{2}{*}{ NFA } & $0.03 * * *$ & $0.29 * * *$ & $0.19 * * * / 0.11 * *$ & $0.04 * * *$ \\
\hline & $(3.75)$ & $(6.56)$ & $(3.97)$ & $(0.00)$ \\
\hline \multirow[t]{2}{*}{ REL } & $0.16^{* * *}$ & $0.14 * *$ & $0.22 * * *$ & $0.19 * * *$ \\
\hline & $(3.41)$ & $(2.57)$ & (3.13) & $(0.00)$ \\
\hline \multirow[t]{2}{*}{$T T$} & $0.09 * * *$ & 0.02 & $0.17 * * *$ & $0.55^{* * *}$ \\
\hline & $(2.77)$ & $(0.51)$ & $(4.12)$ & $(0.00)$ \\
\hline
\end{tabular}

Note: The estimates for DE and IE are obtained using DOLS $(-1,1)$ method which includes one lead and one lag for each variable in the regressions while the ones for SSA, presented in this paper, are obtained from GMM estimator which is a more suitable estimator for unbalanced panels with potentially endogenous regressors. The test statistics are reported in parentheses and estimates for developing economies and industrial economies coefficients are obtained from Lane and Milesi-Ferretti (2004). Moreover, *,** and *** indicate statistical significance at $10 \%, 5 \%$ and $1 \%$ significance level, respectively, as $* \mathrm{p}<.1 ; * * \mathrm{p}<.05 ; * * * \mathrm{p}<.01$. The second NFA coefficient for industrial economies is that obtained in Gagnon (1996). Coefficients for LS economies come from Ricci et.al (2008) and, unlike the estimates for the other economies, the number in parenthesis are p-values, not test statistics like the others as p-values rather than test statistics are reported in the Ricci et.al paper. The large sample economies in Ricci et.al (2008) are a combination of emerging and industrial economies. The developing economies comprises all economies that are the nascent stages of industrialization while the industrial economies comprise all developed economies as recognized by the IMF and World Bank. See Lane and Milesi-Ferretti (2004) for a list of the developing and industrial economies included in their study.

SSA countries are not excluded or immune to this. The economic characteristic we have chosen to study this difference is the degree of openness to trade. This economic characteristic is chosen because it is a variable in the benchmark model and so we can have a theory to compare results with, making our analysis comparable; for instance, with the benchmark theoretical model. 
high openness group as one where countries have an average openness which exceeds global average openness. The low openness group comprises countries whose average openness is below 20 percentage points less than the global average openness while the medium openness group is composed of countries with average openness more than 20 percentage points below the global average. For instance, if the global average openness is $60 \%$, then the high, medium and low openness groups would be countries with openness of $>60 \%,>40 \%$ and $<40 \%$ respectively. The global average openness is the average trade openness of all countries that participate in international trade over the years while the average trade openness of each country is the country's mean openness over the years it has participated in global trade. A summary of the countries in the high, medium and low openness groups can be found in the appendix.

In Table 2.3, the sample is partitioned into three distinct groups, according to the levels of openness. First, our result confirms the existence of a transfer effect when SSA countries are partitioned according to their levels of openness and the result is statistically significant at all levels of openness, with the significance being strongest at low trade openness levels and least at high openness levels. Thus, the level of openness is an important factor that determines the existence and magnitude of a transfer effect in SSA. The theoretical model presented in this paper provides predictions that relate trade openness to the transfer effect, suggesting that for most values of model parameters, the transfer effect, that is the magnitude of the positive impact of NFA on real exchange rates, should decrease as trade openness increases. This prediction has some empirical support in Table 2.3 which shows that the transfer effect is indeed decreasing as we move from low openness to medium and then to high openness. In particular, for the least open group, the near-term point estimate is 0.05 , but for the most open it shrinks to 0.02 and is less significant statistically. To put things in perspective, our findings suggest that on average the magnitude of transfer effect in the least open SSA countries is about three times larger compared to the most open SSA countries.

Nonetheless, the estimated coefficient of the transfer effect remains low and our results continue to confirm that the magnitude of the transfer effect in SSA is generally low when compared to the developed markets, for instance. Reasoning in line with Ricci et.al (2008), this weak or low transfer effect likely reflects the surge in the size of domestic-currency liabilities in most SSA countries in recent decades. The effect of relative per capita output also shows some variation with openness and is significantly negative for the most open group of SSA countries and positive for the least open group. What this suggests is that the BalassaSamuelson (BS) effect is more likely to hold in SSA with the least openness to trade. 
IBHAGUI Transfer Problem in Sub-Saharan Africa

Table 2.3 ${ }^{15}$ : Sample Splits Based on Openness

\begin{tabular}{|c|c|c|c|c|c|c|}
\hline & \multicolumn{2}{|c|}{ Low Openness } & \multicolumn{2}{|c|}{ Medium Openness } & \multicolumn{2}{|c|}{ High Openness } \\
\hline$R E R_{i t-1}$ & & $0.37 * * *$ & 0.04 & & $0.65^{* * *}$ & \\
\hline & & $(8.84)$ & $(0.16)$ & & $(6.71)$ & \\
\hline & $\begin{array}{l}\text { Short } \\
\text { Run }\end{array}$ & $\begin{array}{l}\text { Long } \\
\text { Run }\end{array}$ & $\begin{array}{l}\text { Short } \\
\text { Run }\end{array}$ & Long Run & $\begin{array}{l}\text { Short } \\
\text { Run }\end{array}$ & $\begin{array}{l}\text { Long } \\
\text { Run }\end{array}$ \\
\hline$N F A$ & $\begin{array}{c}0.05^{* * * *} \\
(8.30)\end{array}$ & $0.08 * * *$ & $\begin{array}{c}0.04 * * * \\
(2.65)\end{array}$ & $0.04 * * *$ & $\begin{array}{c}0.02 * * \\
(2.00)\end{array}$ & $0.05 * *$ \\
\hline$T T$ & $\begin{array}{c}0.03 \\
(0.93)\end{array}$ & 0.05 & $\begin{array}{c}0.09 \\
(0.54)\end{array}$ & 0.10 & $\begin{array}{l}-0.15 \\
(1.30)\end{array}$ & -0.42 \\
\hline REL & $\begin{array}{c}0.25^{* * *} \\
(2.96)\end{array}$ & $0.40 * * *$ & $\begin{array}{l}0.29 * * \\
(2.22)\end{array}$ & $0.30 * *$ & $\begin{array}{c}-0.64 * * \\
(2.39)\end{array}$ & $-1.82 * *$ \\
\hline RIRD & $\begin{array}{c}0.0007 * * * \\
(3.37)\end{array}$ & $0.001 * * *$ & $\begin{array}{l}-0.0003 \\
(1.12)\end{array}$ & -0.0003 & $\begin{array}{c}0.0005^{* *} \\
(2.26) \\
\end{array}$ & $0.002 * *$ \\
\hline \multicolumn{7}{|c|}{ Diagnostic Test } \\
\hline Observations & 417 & & 206 & & 389 & \\
\hline Instruments & 36 & & 21 & & 77 & \\
\hline Wald Test & {$[0.000]$} & & {$[0.000]$} & & {$[0.000]$} & \\
\hline $\begin{array}{l}\text { Arellano- } \\
\text { Bond Test ( } p- \\
\text { value) }\end{array}$ & 0.3026 & & 0.1416 & & 0.5086 & \\
\hline Sargan Test & [0.9988] & & [0.9963] & & & \\
\hline
\end{tabular}

\footnotetext{
${ }^{15}$ In fitting each group's data to the model, we are faced with a large time dimension. In this scenario, the traditional wisdom will be less predisposed towards using GMM. In fact, Roodman (2006) finds that if time dimension is large, a more straightforward fixed effects estimator works as a suitable estimator. But the reality of our case is that we are faced with not only a high time dimension but at least one of the variables in the model is endogenous. Consequently, a choice must be made between estimators that address endogeneity and those that accept higher time dimensions, all within an unbalanced panel, as estimators that simultaneously address these concerns for unbalanced panels are yet to be developed. Given the nature of our investigation, and the fact that the occurrence of endogeneity is not something we can wish away, we err with caution and favour results from GMM estimation. Our position is also supported by Judson and Owen (1999) who find that if endogeneity is an issue and the time dimension is large, then GMM can still be used to produce good estimates, albeit with some computational issues which we attempted to contain by lag-limiting to reduce the instrument count. Nonetheless, we also estimate the model using fixed effects and bias-adjusted least square dummy variables techniques that are suitable for higher time dimensions but do not directly address issues of endogeneity. The results give support and validation, albeit in parts, to the conclusions reached with GMM.
} 


\section{Review of Economic Analysis 11 (2019) 325-391}

Notes: Dependent variable is the $\log$ of CPI based RER, ***,**,* denote statistical significance at the $1 \%, 5 \%$, and $10 \%$ levels, respectively. The figures in parenthesis ( ) are modulus $\mathrm{z}$ ratios while figures in brackets [ ] are p-values. P-values more than 0.10 indicates non-rejection of the null. Arellano-Bond Test is the serial correlation/autocorrelation test of Arellano and Bond, where null hypothesis is no serial correlation. Estimation by difference generalized method of moments' estimation technique, model well specified, over identifying restrictions satisfied and instruments valid.

Thus, studies such as Genius and Tzouvelekas (2008) which have found no evidence of the BS effect in SSA have most likely been performed on samples comprising mainly countries with higher-than-average levels of trade openness ${ }^{16}$.

\subsection{Financial Liberalization and Real Exchange Rates}

If financial repression, according to McKinnon (1973) and Shaw (1973), is characterized by extensive government interventions mostly in the financial markets of developing countries, then financial liberalization is the resolve to remove government intervention from financial markets. This process itself is gradual. However, provided there is no contrary policy to limit or eliminate the process, a country is deemed to have adopted financial liberalization once the process is ongoing. According to Akinsola and Odhiambo (2017), most countries in SSA have embraced financial reforms since the mid-1980s in the form of abolishing administrative credit allocation, liberalizing interest rates, improving financial infrastructure and bank regulations and shifting from direct to indirect monetary policy.

More than two decades have passed since financial liberalization gained prominence and acceptance in SSA. Since adopting financial liberalization, the real exchange rates of several SSA countries have exhibited dissimilar characteristics. The possible role of financial liberalization as a driver of the real exchange rates is an important theme that has not been formally studied. Such

\footnotetext{
${ }^{16}$ An intuitive explanation for failure to find the BS effect for highly open SSA countries is that studies such as Kassim (2013) have found that increased participation in international trade on the back of trade liberalization have accelerated import at a higher pace that export, which in turn deteriorates the trade balance of SSA countries over the last decades. Although this deterioration may not necessarily stifle domestic real output, and hence relative output per capita, especially if the imports are capital goods, nonetheless it weakens the real exchange rates as significant portions of the finished goods are not even traded externally due to the sizable amount of nontradable goods in the aggregate output of SSA countries. For terms of trade, we surprisingly fail to find any significant evidence that its effects on real exchange rates varies with the degree of openness to trade in SSA. Finally, our results confirm that where significant, real interest rate differentials have a positive and statistically significant effect on real exchange rates in SSA, in line with Baxter (1994), and this is true for both high and low levels of trade openness. However, the estimated coefficient remains stubbornly infinitesimal as in the previous section; this continues to suggest that real interest rates differentials' impact on real exchange rates in SSA is not economically significant. Thus, we exclude real interest rates differentials from our analysis in the subsequent sections where we analyse how financial liberalization has impacted real exchange rates in SSA
} 
studies are important because it is central for SSA policymakers to understand the consequences of adopting financial liberalization, and whether such a policy should be continued or eschewed. Furthermore, examining the role of financial liberalization as a real exchange rate driver improves our understanding of the behavior of the real exchange rates, reducing uncertainty in the domestic economy and thus enabling investors to make the right decision on current and future investment plans. Financial liberalization reduces barriers to capital flows and enhances financial integration. These consequences of financial liberalization are the possible mechanisms through which it affects the real exchange rates. In this section, we present empirical evidence on the impact of financial liberalization on real exchange rates in SSA. Our aim is to elucidate the linkages between financial liberalization and the real exchange rates. As a starting exercise, we provide below some descriptive statistics which offer a preliminary insight into the behavior of real exchange rates across some SSA countries following the adoption of financial liberalization.

Table 2.4 shows the average real exchange rates for a selected number of SSA countries before and after financial liberalization. The averages are determined solely to help us understand the relative magnitude of the real exchange rates before and after liberalization. Our inferences are based on formal econometric investigation and not these averages. From the table, it is seen that real exchange rates depreciated on average following the adoption of financial liberalization in most of the SSA countries in our sample. This position is also supported by the graphs detailing a downward evolution of real exchange rates in SSA post financial liberalization.

The rate of change of real exchange rates post financial liberalization varies among countries. Figure 2.1 shows that the fall in average real exchange rate post financial liberalization is largest in Ghana and smallest in Kenya. Overall, the unanimous preliminary result from the summary statistics is that on average the real exchange rates have weakened in SSA since adopting financial liberalization. Although interesting and revealing, this outcome only provides a preliminary or merely descriptive information on real exchange rates behaviour post financial liberalization. It neither provides a proper evidence nor investigate the relationship empirically, using econometric methods, to formally ascertain if there indeed exists a link between real exchange rates and financial liberalization and the validity of such links in the light of other real exchange rates determinants. Motivated by this vacuum, we are interested in empirically investigating whether the behaviour of real exchange rates in SSA following financial liberalization was just a mere coincidence or whether it can in parts be attributable to the adoption of financial liberalization. Thus, in the empirical analysis that follows, we formally investigate and test whether there exists a significant link between financial liberalization and real exchange rates in SSA. 
Meanwhile, the highly persistent and possibly nonstationary nature of the real exchange rate is well known and documented in the literature. However, we note that even with nonstationary, it is still possible to describe its movements, in light of its drivers, provided its one period lag is included in the empirical specification as it cointegrates with its one period lag, implying that its one period difference is stationary. Thus, we follow Sims (2013) and include lagged one-period real exchange rate as a regressor in our empirical model.

Table 2.4: Average Real Effective Exchange Rates Before and After Financial Liberalization

\begin{tabular}{|l|c|c|}
\hline Country & $\begin{array}{l}\text { Average Real Exchange } \\
\text { Rate } \\
\text { Financial Liberalization }\end{array}$ & $\begin{array}{c}\text { Average Exchange Rate } \\
\text { After Financial Liberalization }\end{array}$ \\
\hline Angola & 102.78 & 92.76 \\
\hline Botswana & 106.23 & 101.92 \\
\hline Burkina Faso & 192.5 & 106.04 \\
\hline CAF & 176.37 & 108.31 \\
\hline Congo & 251.93 & 105.68 \\
\hline Gabon & 182.64 & 116.82 \\
\hline Gambia & 240.46 & 134.92 \\
\hline Ghana & 504.6 & 104.68 \\
\hline Guinea-Bissau & 163.98 & 95.97 \\
\hline Kenya & 93.48 & 92.04 \\
\hline Madagascar & 187.69 & 104.15 \\
\hline Malawi & 206.03 & 135.65 \\
\hline Mali & 169.82 & 112.16 \\
\hline Mauritania & 209.72 & 115.81 \\
\hline Mauritius & 118.65 & 112.22 \\
\hline Mozambique & 248.345 & 105.11 \\
\hline Namibia & 108.99 & 97.85 \\
\hline Niger & 174.49 & 106.89 \\
\hline Senegal & 152.28 & 106.65 \\
\hline South Africa & 168.94 & 115.13 \\
\hline Togo & 140.23 & 101.65 \\
\hline Uganda & 154.81 & 113.02 \\
\hline Zambia & 158.57 & 106.98 \\
\hline
\end{tabular}


Figure 2.1: Comparison of Average Real Effective Exchange Rates before and After Liberalization

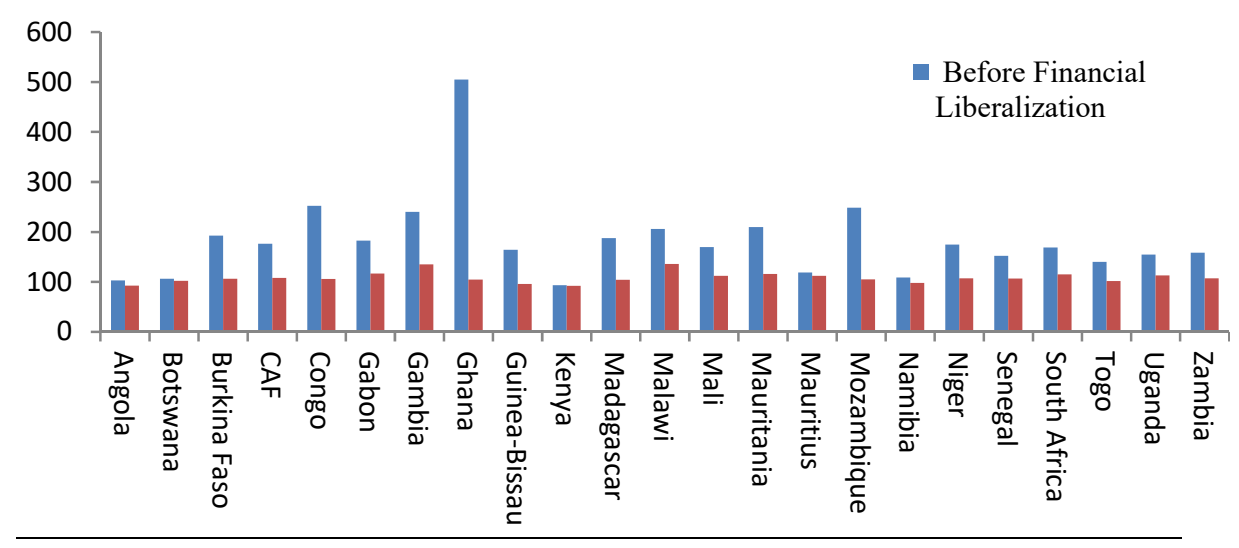

Figure 2.2: Differences in Average Real Effective Exchange Rates before and After Liberalization

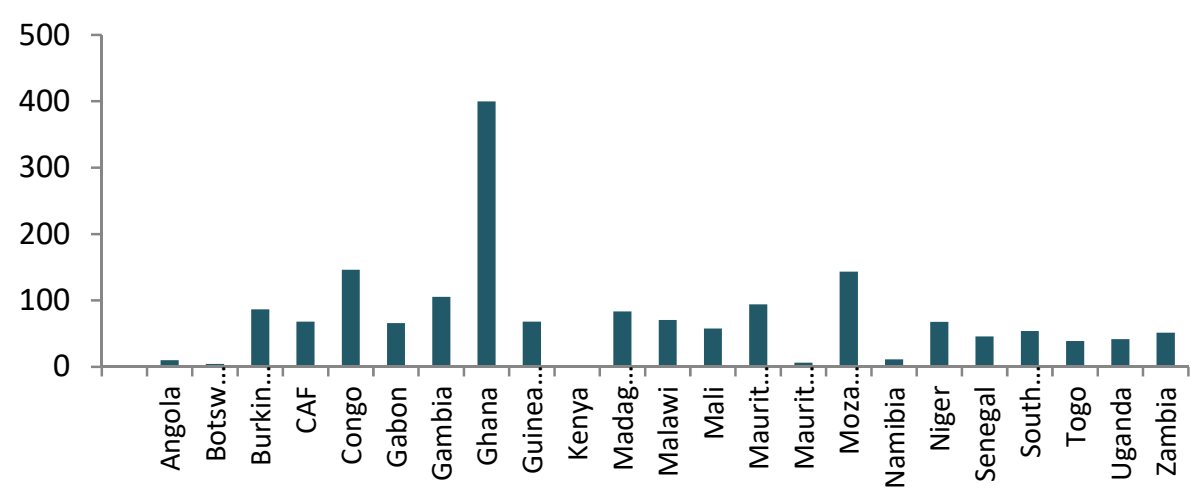

Note: The real effective exchange rates data used for plotting these bar charts comes from Davas $(2012,2016)$. The countries presented here are illustrative and are a subset of the countries used for this study. They represent the two extremes - countries with the highest and lowest change, fall, in average real exchange rates before and after finlib - and all other countries in-between. The full sample of countries, alongside their exchange rates behaviours before and after financial liberalization, including liberalization dates, can be found in the Appendix.

As Sims (2013) notes, including lagged dependent variable as a regressor rids of spurious coefficients and makes it possible to escape the problem of spurious estimation because the cointegration between the variable and its lagged value ensures that estimated coefficients are 
super consistent, with faster than normal convergence. Although standard inference becomes distorted, Sims (2013) also notes that test statistics from specifications which include lagged dependent variable will not result in large biases that sabotage inference.

\subsubsection{Empirical Model Specification}

We will test the hypothesis that financial liberalization is linked with real exchange rates in SSA. To achieve this, we combine disparate strands of previous empirical work that has identified the different determinants of real exchange rates and empirically extend the Lane and Milesi-Ferreti (2004) model to include financial liberalization. Accordingly, we include financial liberalization to the list of real exchange rates determinants and estimate a simple panel model of the form ${ }^{17}$

$$
R E R_{i t}=\alpha_{i}+\beta_{1} F L I B_{i t}+\beta_{2} N F A_{i t}+\beta_{3} T O T_{i t}+\beta_{4} R E L_{i t}+\varepsilon_{i t}
$$

where $R E R$ is the real effective exchange rate, $\alpha_{i}$ is the country-specific fixed effect, $N F A$, TOT and REL measure the net foreign assets, terms of trade and relative per capita output, respectively, and $\varepsilon_{i t}$ is the idiosyncratic error term. Also, $\beta_{3}$ and $\beta_{4}$ denote elasticities with respect to real exchange rates of terms of trade and relative per capita output, while the rest coefficients are semi elasticities of their respective variables. FLIB is a dummy variable representing financial liberalization and assumes a value of 1 from the year a given SSA country adopted financial liberalization and 0 otherwise. It is unclear what impact FLIB would have on real exchange rates, although the preceding descriptive statistics suggests a weakening of the real exchange rates after financial liberalization, implying that $F L I B$ in that sense bears a negative impact on $R E R$, so that $\beta_{1}<0$. This is the main question this section sets out to answer.

Another pertinent question to be answered in this section is how financial liberalization impacts the transfer effect in SSA. In this instance, we ask whether financial liberalization alters the sufficiently overwhelming evidence of the existence of a (low) transfer effect in SSA obtained in the previous sections. That is, how financial liberalization influences the coefficient $\beta_{2}$ - the NFA semi elasticity of real exchange rates. Hence, we interact FLIB and NFA and use this interaction term as a regressor to examine whether financial liberalization significantly influences the responsiveness of RER to $N F A$. Based on this, the appropriate empirical specification is given by

\footnotetext{
${ }^{17}$ Net foreign assets and financial liberalization dummy are not expressed in logarithm in order to be agreement with/match the original theory model in section 2.2
} 


$$
\begin{gathered}
R E R_{i t}=\alpha_{i}+\beta_{1} F L I B_{i t}+\beta_{2} N F A_{i t}+\beta_{3} T O T_{i t}+\beta_{4} R E L_{i t} \\
+\beta_{5}\left(N F A_{i t} \times F L I B_{i t}\right)+\varepsilon_{i t}
\end{gathered}
$$

where $N F A_{i t} \times F L I B_{i t}$ represents the interaction between net foreign assets and financial liberalisation. Following Alfaro et.al. (2004), we add each variable in the interaction term to the regression to ensure that the interaction term proxies for neither financial liberalization nor net foreign assets. Based on the theory model, previous studies and some results obtained in the earlier section, the expected signs of coefficients are $\beta_{2}, \beta_{3}, \beta_{4}>0$. Although we expect that $\beta_{1}<0$ based on the preliminary descriptive statistics, it is largely unclear what $\beta_{1}$ and $\beta_{5}$ should be. It is this lack of clarity that forms the basis of the empirical analysis presented in this section.

\subsubsection{Panel Data Results}

Table 2.5 presents the results of the estimated coefficients on the variables in (2.32). To provide some form of results comparison or robustness checks, we perform the estimation using both GMM and bias- adjusted LSDV, where 'bias-adjusted' implies that any bias emanating from $N$ not being significantly larger than $T$ has been corrected, implying that the bias-adjusted LSDV works well with panels for which $N$ is moderate. The adjusted LSDV calculates bias-corrected LSDV estimators for the standard autoregressive panel data model using the bias approximations in Bruno (2005a), who extends the results by Bun and Kiviet (2003) and Kiviet (1995, 1999). Both GMM and bias-adjusted LSDV estimators also help in specifying a dynamic panel model to examine the effect of financial liberalisation on real exchange rates in SSA and enables the computation of long run coefficients from short run coefficients. We also include for further comparison the standard fixed effects estimator of our parameter of interest. Although the bias-adjusted and fixed effects estimators require exogeneity of regressors, we can utilise them because our variable of interest, being financial liberalization, for the most part is taken as exogenous as it does not bear a reverse simultaneous relationship with real exchange rates. For the other variables, however, we rely more on results from GMM since this estimator removes any bias emanating from potential endogeneity. Meanwhile, all 3 estimators have a common, joint advantage in that they are appropriate for different kinds of panels, including unbalanced panels. Results are presented below.

All estimated coefficients obtained using GMM, corrected LSDVC and fixed effects (FE) estimators are presented in columns I, II and III respectively and reported in Table 2.5 above. For column III, we have used the FE estimator rather than random effects (RE) estimator because the Hausman test indicates that FE is more appropriate. 
Table 2.5: Financial Liberalization and Real Exchange Rates

\begin{tabular}{|c|c|c|c|c|c|}
\hline \multirow[b]{2}{*}{$R E R_{i t-1}$} & \multicolumn{2}{|c|}{$\begin{array}{c}\text { (I) } \\
\text { GMM }\end{array}$} & \multicolumn{2}{|c|}{$\begin{array}{c}\text { (II) } \\
\text { Corrected LSDV }\end{array}$} & \multirow{2}{*}{$\begin{array}{c}\text { (III) } \\
\text { Fixed Effects } \\
- \\
\end{array}$} \\
\hline & 0.700 & & 0.830 & & \\
\hline & $(16.33)$ & & $(53.02)$ & & - \\
\hline & Short Run & Long Run & Short Run & Long Run & - \\
\hline \multirow[t]{2}{*}{$F L I B$} & $-0.10^{* *}$ & $-0.33 * *$ & $-0.04 * * *$ & $-0.24 * * *$ & $-0.20 * *$ \\
\hline & $(2.53)$ & & $(4.23)$ & & $(12.09)$ \\
\hline \multirow[t]{2}{*}{$N F A$} & $0.08 * *$ & $0.27 * *$ & $0.02 * * *$ & $0.19 * * *$ & $0.05 * * *$ \\
\hline & $(2.11)$ & & $(2.79)$ & & $(3.10)$ \\
\hline \multirow[t]{2}{*}{$T T$} & $0.13 * * *$ & $0.43 * * *$ & $0.04 * *$ & $0.24 * *$ & $0.10 * * *$ \\
\hline & $(3.28)$ & & $(2.14)$ & & $(2.74)$ \\
\hline \multirow[t]{2}{*}{$R E L$} & -0.06 & -0.20 & 0.002 & 0.012 & $0.13 * * *$ \\
\hline & $(0.98)$ & & $(0.10)$ & & $(3.22)$ \\
\hline \multirow[t]{2}{*}{$\left(N F A_{i t} \times F L I B_{i t}\right)$} & $-0.08 * *$ & $-0.27 * *$ & $-0.02 * *$ & $-0.106^{* *}$ & $-0.04 * *$ \\
\hline & $(2.26)$ & & $(2.28)$ & & $(2.68)$ \\
\hline \multicolumn{6}{|c|}{ Diagnostics Test } \\
\hline$R^{2}$ & - & & - & & 0.10 \\
\hline Observations & 1,029 & & 1,029 & & 1,099 \\
\hline F-stat (p-value) & - & & - & & {$[0.000]$} \\
\hline $\begin{array}{l}\text { Hausman FE/RE } \\
\text { Test - }\end{array}$ & & & - & & {$[0.026]$} \\
\hline Instruments & 72 & & - & & - \\
\hline Wald Test & {$[0.0000]$} & & - & & - \\
\hline $\begin{array}{r}\text { Arellano-Bond Test } \\
(p \text {-value })\end{array}$ & {$[0.1820]$} & & - & & - \\
\hline Sargan Test & {$[0.2570]$} & & - & & - \\
\hline
\end{tabular}

Notes: Dependent variable is the $\log$ of CPI based RER, ***,**,* denote statistical significance at the $1 \%, 5 \%$, and $10 \%$ levels, respectively. The figures in parenthesis ( ) are modulus $\mathrm{z}$ ratios while figures in brackets [ ] are p-values. P-values more than 0.10 indicates non-rejection of the null. Arellano-Bond Test is the serial correlation/autocorrelation test of Arellano and Bond, and Sargan Test is the test of over identifying restriction proposed by Sargan. Estimation by difference generalized method of moments' estimation technique, model is well specified, over identifying restrictions are satisfied and instruments are valid. Hausman test for FE/RE rejects the null of RE at $5 \%$ level, so the FE is favoured.

The GMM results in column (I) shows that lagged dependent variable has a relatively high coefficient of 0.70 , implying a substantial difference between short run and long run estimates. 
Financial liberalization depreciates real exchange rates by 10 percent in the short run and 33 percent in the long run, and the finding is statistically significant.

Moreover, as expected, net foreign asset bears a positive relationship with real exchange rates, so that a 10 percentage point increase in net foreign assets position appreciates the real exchange rates by around 1 percent in the short run and 2.7 percent in the long run. For terms of trade and relative per capita output, the results are different. While terms of trade are in line with expectations, the findings for relative per capita output are at best largely mixed. Specifically, a 10 percentage point rise in terms of trade strengthens real exchange rates by 1.3 percent in the short run while it increases real exchange rates by more than three times as much, at 4.3 percent, in the long run. However, no evidence exists that relative per capita output bears a significant relationship with real exchange rates, both in the short and long run. Finally, we find that financial liberalization dampens the effect of net foreign assets on real exchange rates - in the presence of financial liberalization, a 10 percentage point rise in net foreign assets, rather than strengthen, actually weakens the real exchange rates by 0.8 percent in the short run and 2.7 percent in the long run. The p-value of the serial correlation test shows that the error term is not serially correlated of the second degree and our model is on average well specified while the validity of instruments used is confirmed by the p-value of the Sargan test.

In the LSDVC results in column II, like the GMM, the short run impact represents the coefficients on the variables while the long run impact is obtained by scaling or dividing the short run coefficients by one minus the coefficient of the dynamic term which is the lagged dependent variable. This scaling factor represents the speed of adjustments. The results in column II show that the estimated coefficient on lagged dependent variable is high, at 0.83 , and this again implies a significant difference between short run and long run estimates of the variables under study. As in column I, the results suggest that financial liberalization deteriorates real exchange rates by 4 percent in the short run and 24 percent in the long run, clearly accentuating the significant gap or difference between the short and long run effects. Moreover, net foreign assets and terms of trade impact real exchange rates positively while, as in column I, there is no evidence of a relationship between relative per capita output and real exchange rates. For net foreign assets and terms of trade, the result suggests that a 10 percentage point increase in net foreign assets and a 10 percent rise in terms of trade appreciate the real exchange rates by 0.2 and 0.4 percent in the short run and 1.9 and 2.4 percent in the long run, respectively. For relative per capita output, the result is both statistically and economically insignificant. Again, the interaction term is negative and significant and we find evidence that financial liberalization dampens the transfer effect in SSA. The evidence is such that, with financial liberalization, a 10 percentage point increase in net foreign assets weakens real exchange rates by 0.2 and 1.1 percent in the short and long run, respectively.

In column (III), we find that the main results are mostly similar to those in columns I and II with respect to signs and statistical significance. Essentially, financial liberalization is 
statistically significant and depreciates real exchange rates by 20 percent. Net foreign assets again remain statistically significant, reiterating the presence of a transfer effect, with its coefficient increasing marginally. In addition, a 10 percent increase in terms of trade is associated with a 1 percent rise in real exchange rates. Column (III) also indicates that a 10 percent increase in relative per capita output (the per capita output of SSA countries relative to trading partners) raises real exchange rates by 1.3 percent. In addition, the interaction term remains negative and significant so that the conclusion that a move to financial liberalization dampens the transfer effect continues to remain valid.

Put together, the results provided by all estimators unanimously confirm that financial liberalization is an important variable that possibly drives the behavior of real exchange rates in SSA. In column I, the GMM estimator suggests that financial liberalization significantly depreciates real exchange rates by up to 33 percent in the long run. In column II, the biasadjusted LSDV estimator shows that adopting financial liberalization weakens the real exchange rates by around 24 percent in the long run while the FE estimator suggest that the fall in real exchange rates following the adopting of financial liberalization in SSA is about 20 percent. Another interesting and consistent finding is that the evidence of a transfer effect in SSA is unaltered and continues to remain valid in that, for the main effect, we continue to find that an increase in net foreign assets strengthens real exchange rates in SSA - though the magnitude of the transfer effect remains small. In addition, keeping all factors constant, the results suggest that increases in terms of trade lead to appreciation of real exchange rates in SSA. However, against earlier results, we surprisingly find that the hypothesis that increases in relative per capita output strengthen real exchange rates is no more unanimously supported. Of the three estimators, only the FE estimator finds a positive and significant relationship between relative per capita output and real exchange rates, the other estimators provide conflicting signs and are not significant. Thus, the evidence that relative per capita output strengthens real exchange rates is weak in SSA when other plausible real exchange rates determinants are controlled for.

Moving to the interaction term, which is the interaction between financial liberalization and net foreign assets, we find that the coefficient on the interaction term turns out negative, with strong levels of statistical significance, in all three columns. It is significant at the $5 \%$ level for the entire range of estimators. This provides some evidence that financial liberalization is a real exchange rates determinant that dampens the transfer effect in SSA. In particular, the GMM estimator suggests that financial liberalization reduces the magnitude of transfer effect by 27 percent in the long run while the adjusted LSDV and FE estimators imply a reduction of 11 and 0.4 percent, respectively, following a 10 percentage point rise in net foreign assets.

On the whole, three main inferences, on the back of the above findings, emerge from the empirical exercise conducted in this section. First, and foremost, we find some links between financial liberalization and the real exchange rates in SSA; financial liberalization relates to a 
real depreciation in SSA. Second, we find that the evidence of the existence of a small but significant transfer effect in SSA is strong and remains true and unaltered even after controlling for other possible real exchange rate determinants. Third, our finding suggests that financial liberalization dampens the impact of a transfer effect in SSA. Although we place more emphasis on estimates from the GMM estimator given the estimator's many advantages, nevertheless our central findings are robust across estimators and largely unaltered by the choice of estimators as the three estimators, in most instances, reach similar conclusions.

Taken together, what we learn from the result - that further adoption of financial liberalization dampens the transfer effect in SSA - can be interpreted as follows: financial liberalization reduces barriers to capital inflows so that, although an increase in net foreign assets in SSA via further foreign asset purchases is still possible, the plausible increase in capital inflows or foreign liabilities implies larger outflows of interest on foreign liabilities than inflows on foreign assets; this is because of the historically higher rate of return required to attract capital inflows to SSA countries to compensate for the higher risk in the region, and the significantly lower rate of return demanded/required to attract capital outflows away from SSA into more advanced climes. The higher interest payment on foreign liabilities, or negative net investment income, possibly has a dominating effect in the presence of financial liberalization, leading to a real depreciation in SSA even with a rise in net foreign assets.

\subsection{Conclusion}

Does financial liberalization tell us anything about the behavior of real exchange rates in SSA? Put differently, how has financial liberalization impacted the real exchange rates in SSA? Such a question has become increasingly prominent and relevant as ever, especially since the outset of financial liberalization in the 1980's and 1990's in SSA. Additionally, lurking behind this question is yet another no less important question - is there an evidence of a transfer effect in SSA?

The literature so far has not considered the way in which financial liberalization affects the real exchange rates of SSA countries. The literature on the determinants of real exchange rates has made some progress in studying the productivity effects, terms of trade effects and the transfer problem. And even then, such studies are sparse for developing countries and largely non-existent for SSA. Existing studies mostly concentrate on the euro area, and other industrialized economies. Other recent studies have examined how real exchange rates movements impact a host of macroeconomic variables, as well as their respective policy implications, but not as much studies have examined in good depth the response of real exchange rates to macroeconomic fundamentals, especially in SSA. Motivated by this vacuum, the aim of this paper has been to establish the determinants of real exchange rates in SSA particularly to assess the existence of a transfer effect in SSA as well as to investigate the impact that a move to financial liberalization has on real exchange rates in SSA. 
To this end, we extend existing studies in an empirical setting to include financial liberalization and apply established empirical techniques to estimate model coefficients. Our goal has been to answer a question for which convincing empirical evidence appears to be largely missing, namely "how has financial liberalization collectively impacted the real exchange rates of SSA countries" Our focus on SSA is motivated by the fact that many countries in the region were the last to adopt financial liberalization and there were heated debates that preceded the launch of financial liberalization in the region, notable of which was the fear that if SSA countries were to adopt financial liberalization, they could become more exposed to shocks to the global economy which could have rippling effects on the economy, some of which could be asymmetric effects by nature, and the resulting diverging patterns of macroeconomic performances could have adverse implications on economic variables, inclusive of real exchange rates, and further stunt economic prosperity and performance and impoverish the region. Over two decades have passed since adoption of financial liberalization, and we believe it is now time to assess whether some of the earlier held and hotly debated concerns were justified, particularly the links between financial liberalization and the real exchange rates.

We also look at the impact on real exchange rates of movements in net foreign assets which allow us to test for the existence of a transfer effect in SSA. One notable reason we have focused on real exchange rates is that they are a major measure of external positioning and are thus an important consideration when analyzing macroeconomic conditions in open economies and are crucial in the current debate on SSA region's future, notably since the planned launch by SSA policy makers of a scheme aimed at stabilizing benign economic conditions, given the composition and sometimes comparability of economies in the region.

Our broad findings are as follows. The first key result of the paper is that there is an evidence of a transfer effect in SSA. This means that increases in net foreign assets positions are accompanied by appreciation of real exchange rates while decreases in net foreign assets are accompanied by real exchange rates depreciation. Moreover, the transfer effect is decreasing in openness. We find that the sign of the estimated coefficient on net foreign assets, which provides the evidence of a transfer effect, is robust to controlling for other plausible real exchange rates determinants and the estimation technique utilized. We also find that this relationship depends on whether or not financial liberalization is adopted. Indeed, with financial liberalization, we find, as one of the paper's key highlights, that the estimated response of real exchange rates to net foreign assets changes. Specifically, with financial liberalization, the transfer problem is reversed as an increase in net foreign assets position depreciates, rather than appreciates, the real exchange rates. This finding is robust to different methods of estimation, although the magnitude of depreciation tends to vary slightly across estimators. A policy implication of this finding is that for countries to have a non-zero increase in net foreign assets 
position and yet be unburdened by the transfer problem, they would need to be well liberalized financially.

Another notable result in this paper is that financial liberalization has weakened real exchange rates in SSA. In order words, financial liberalization is negatively related to real exchange rates in SSA as the adoption of financial liberalization has significantly depreciated real exchange rates in SSA. Our results suggest that a move to financial liberalization depreciates the real exchange rates by up to 20-33 percent. Our empirical results also suggest that contrary to some highlighted studies, the effects of terms of trade and relative per capita output on real exchange rates are overall not consistently robust. We note that it remains a puzzle that many SSA countries were constrained by weak economic growth for the most part of the previous decades despite the weakening pressure of financial liberalization on real exchange rates which should feed positively to the export sector and possibly boost growth. This seems to suggest a weak export sector and the existence of a sizable amount of nontradables in SSA output, so that a depreciated or undervalued real exchange rates does not necessary boost growth via improved exports, a view that is in line with Magud and Sosa (2010) who posit that positive evidence of undervaluation of real exchange rates on growth is mixed and inconclusive. Although our focus in the present paper has nothing to do with growth, yet it is interesting and important to mention what a depreciated real exchange rate is expected to achieve, at least in theory, but has not achieved, at least in the context of SSA. This in some ways may not be unconnected with the import dependent nature, on average, of many SSA countries.

In summary, this paper has presented financial liberalization and net foreign assets position, among others, as determinants of real exchange rates in Sub-Saharan Africa (SSA). Utilizing a testable theoretical model inspired by Lane and Milesi-Ferretti (2004), and newly constructed data sets for real exchange rates, net foreign assets, and financial liberalization, we uncover the response patterns of SSA countries' real exchange rates to financial liberalization and net foreign assets movements. This enables us to argue that financial liberalization is an important determinant of real exchange rates in SSA, show that real exchange rates have depreciated since adoption of financial liberalization, and confirm the existence of a small but robust and significant transfer effect that decreases with increases in openness. Our result also provides evidence that financial liberalization dampens the positive semi-elasticity of net foreign assets with respect to real exchange rates, so that the transfer effect is reversed, implying that a decrease in net foreign assets position leads to real exchange rates appreciation, rather than depreciation, when there is a move to financial liberalization.

Looking ahead, the findings presented in this paper suggest possible dissimilarities in the impact of the identified real exchange rates determinants for different economic characteristics. For instance, without considering openness as an economic characteristic, the variation in severity of the transfer problem in SSA would not have been visible. When openness is 
considered, the results show that the transfer effect is decreasing in openness, as suggested by the theoretical model, hinting that other economic characteristics that can alter the magnitude of the impact of the identified drivers of real exchange rates might exist. Therefore, future research could consider identifying and modelling such economic characteristics in a theoretical framework perhaps similar to the one presented in this paper. The framework could be extended to include adjustment costs on external asset holding in a dynamic general equilibrium framework that incorporates features such as wealth effects and imposes varying characteristics of bonds that can be held or issued. Another important area of possible extension for future work, currently constrained by lack of data, is to analyze the impact of valuation (the effects of changes in valuation) on net investment income in SSA whenever relevant datasets become available in the near future.

Importantly, SSA countries are in general not completely homogeneous. This is due to differences in factors such as geopolitics, institutional quality and the rule of law, among many others. Potentially, these differences could alter how financial liberalization evolves across countries and its influence on the transfer effect. For example, it could be that countries with saner geopolitics, better rule of law and higher institutional quality are able to better reap the benefits of financial liberalization than those with less developed systems. Bruneau et al. (2017) have argued that large capital flows and their links to asset markets varies across countries and depend, among others, on a host of factors that include the depth of the domestic financial systems and the quality of institutions. Alfaro et al. (2004) have shown that a well-developed domestic financial system releases the benefits of FDI inflows. In view of the foregoing, a potential area for future research examining the transfer effect in SSA would be to account for potential heterogeneity across countries, both in terms of differences in the 1) stages of political advancement and 2) real and financial institutional quality.

\section{References}

Aglietta, M., Baulant, C. and Coudert. V. (1997). Why the Euro will be Strong: An Approach Based on Equilibrium Exchange Rates, CEPII Document De Travail No. 18. Paris.

Aipi, B. (2012). Determinants of Real Exchange Rate in Papua New Guinea. Bank of Papua New Guinea Working Paper BPNGWP2012/04.

Alfaro, Laura, Areendam Chanda, Sebnem Kalemli-Ozcan, and Selin Sayek, (2004), FDI and Economic Growth: The Role of Local Financial Markets, Journal of International Economics, Vol. 64, No. 1, pp. 89-112.

Akinsola, F.A., and Odhiambo, N.M (2017). The impact of financial liberalization on economic growth in sub-Saharan Africa. Cogent Economics and Finance,5,1- 11

Alberola, E. (2003). Real Convergence, External Disequilibria and Equilibrium Exchange Rates in EU Acceding Countries. Banco de España. mimeo. 
Alberola, E., López, H. and Servén, L. (2004). Tango with the Gringo: the Hard Peg and Real Misalignment in Argentina, World Bank Policy Research Working Paper 3322, June, World Bank, Washington DC.

Alberola, E., Cervero, S. G., Lopez, H. and Ubide, A. (1999). Global Equilibrium Exchange Rates: Euro, Dollar, "Ins," "Outs," and Other Major Currencies in a Panel Cointegration Framework. IMF Working Paper No. 175.

Alberola, E., Cervero, S. G., Lopez, H. and Ubide, A. (2002). Quo vadis Euro? The European Journal of Finance. 8. pp. 352-370.

Alexius, A. and Nilsson, J. (2000). "Real Exchange Rates and Fundamentals: Evidence from 15 OECD Countries", Open Economies Review, 11, pp.383-397.

Balassa, B. (1964). The Purchasing-Power Parity Doctrine: A Reappraisal, Journal of Political Economy, 72(6), 584-596.

Binder, M. and Offermanns, C. J. (2007). International Investment Positions and Exchange Rate Dynamics: A Dynamic Panel Analysis. CESifo Working Paper No. 2095.

Baxter, M., 1993, Real exchange rates, real interest rates, and government policy: Theory and evidence, Manuscript, Nov. (Department of Economics, University of Virginia, Charlottesville, VA)

Baxter, M. (1994). Real exchange rates and real interest dißerentials: Have we missed the business-cycle relationship? Journal of Monetary Economics, 33, 5-37.

Barro, R.J., 1983, Real determinants of real exchange rates, Manuscript (Department of Economics, University of Chicago, Chicago, IL).

Bleaney, M. and Tian, M. (2014). Net Foreign Assets, Real Exchange Rates and Net Exports Revisited. Centre for Research in Economic Development and International Trade, CREDIT Research Paper No. 13/04.

Broner, Fernando, Loayza, N. and Lopez, H. (1997). Misalignment and Fundamentals: Equilibrium Exchange Rates in Seven Latin American Countries, mimeo, World Bank.

Bruneau, G., Leboeuf, M., and Nolin, G. (2017) 'Canada's International Investment Position: Benefits and Potential Vulnerabilities', Bank of Canada Financial System Review

Calderon, C. (2002). Real Exchange Rates in the Long and Short Run: A Panel Co-Integration Approach. Central Bank of Chile Working Papers No 153.

Candelon, B., Kool, C., Raabe, K. and Veen, T. (2007). Long-run Real Exchange Rate Determinants: Evidence from Eight New EU Member States, 1993-2003, Journal of Comparative Economics, 35, pp.87-107.

Carrera, J. and Restout, R. (2008 )Long Run Determinants of Real Exchange Rates in Latin America. Working paper GATE 08-11. <halshs-00276402>

Cashin, Paul, Cespedes, L. and Sahay, R. (2004). Commodity Currencies and the Real Exchange Rate," Journal of Development Economics, vol. 75, 239-268. 
Chen, Yu-chin, and Rogoff, K. (2003). Commodity Currencies," Journal of International Economics, 60(1), 133-160.

Choudhri, E. and Khan, M. (2005). Real Exchange Rates in Developing Countries: Are BalassaSamuelson Effects Present", IMF Staff Papers, 52, 3, pp.387-409.

Christopoulos, C. K., Gentes, K. and Leon-Ledesma, M. A. (2008). Net Foreign Assets, Productivity and Real Exchange Rates in Constrained Economies. School of Economics, Australian School of Business: School of Economics Discussion Paper: 2008/17.

Coudert, V., Couharde, C. and Mignon, V. (2008). Do Terms of Trade Drive Real Exchange Rates? Comparing Oil and Commodity Currencies. Working Paper No 2008- 32.

Coudert, V., Couharde, C. and Mignon, V. (2013). On the Impact of Oil Price Volatility on the Real Exchange Rate - Terms of Trade Nexus. CEPII Working Paper No 2013-40.

De Gregorio, J. and Wolf, H. C. (1994). Terms of Trade, Productivity and the Real Exchange Rate", NBER Working Paper 4807, National Bureau of Economic Research, Cambridge, MA.

Drine, I. And Rault, C. (2004). On the Long-Run Determinants of Real Exchange Rates for Developing Countries: Evidence from Africa, Latin America and Asia. Eurequa, Sorbonne University.

Egert, B., Lahrèche-Révil, A. and Lommatzsch, K. (2005). The Stock-Flow Approach to the Real Exchange Rate of CEE Transition Economies. DIW-Berlin. mimeo.

Faruqee, H. (1995). Long-Run Determinants of The Real Exchange Rate: A Stock-Flow Perspective," International Monetary Fund Staff Papers 42.

Fowowe, B, (2008). Financial liberalization policies and economic growth: panel data evidence from Sub-Saharan Africa, African Development Bank, 20 (3) (2008), pp. 549-574.

Gagnon, J. E. (1996). Net Foreign Assets and Equilibrium Exchange Rates: Panel Evidence. Board of Governors of the Federal Reserve System International Finance Discussion Paper 574, December.

Griffoli, T. M., Meyer, C., Natal, J. and Zanetti, A. (2014). Determinants of the Swiss Franc Real Exchange Rate. Swiss National Bank Working Papers 8/2014.

Gubler, M. and Sax, C. (2017). The Balassa-Samuelson Effect Reversed: New Evidence from OECD Countries. SNB Working Papers, 1/2017.

Girardi, A. and Paesani, P. (2007). The Transfer Problem in the Euro Area. Open Econ Rev, 19:517-537 DOI 10.1007/s11079-007-9058-0.

Jacques, R. (1929). Mr. Keynes' Views on the Transfer Problem. Economic Journal 39 (155): 388-408.

Joyce, J. and Kamas, L. (2003). Real and nominal determinants of real exchange rates in Latin America: Short-run dynamics and long-run equilibrium, Journal of Development Studies, 39:6, 155-182, DOI: 10.1080/00220380312331293617. 
Kakkar, V, and Isabel Y, (2014). "Determinants of Real Exchange Rates: An Empirical Investigation", Bank of Finland, Institute for Economies in Transition Discussion Papers, No. 1/2014, January, Helsinki: BOFIT.

Keynes, J. M. (1929). The German Transfer Problem; “The Reparation Problem: A Discussion. II. A Rejoinder; Views on the Transfer Problem. III. A Reply, Economic Journal 39, March, 1-7; June, 172-8; September, 404-8.

Mariano, C. N., Sablan, V. F., Sardon, J. R. C. and Paguta, R. B. Lane P.R, and Milesi-Ferretti GM (2002). External wealth, the trade balance, and the real exchange rate. IMF Working Papers (02/51).

Lane P.R, and Milesi-Ferretti G. M., (2004). The transfer problem revisited: net foreign assets and the real exchange rate, Review of Economics and Statistics, 86, 841-857.

Lane P.R, and Milesi-Ferretti G.M, (2007). The external wealth of nations mark II: Revised and extended estimates of foreign assets and liabilities, 1970-2004, Journal of International Economics 73, 223-250.

Lane, P.R, and Schmukler, S (2007). International financial integration of China and India, in A Winter and S Yusuf(eds), Dancing with the giants: China, India and the global economy, the World Bank, pp 101-32.

Lane, P.R (2001). The New Open-Economy Macroeconomics: A Survey, Journal of International Economics 54, 235-266.

Lane, P.R. and Shambaugh J.C (2010a). Financial Exchange Rates and International Currency Exposures, American Economic Review 100(1), 518-540.

Lane, P.R., and Milesi-Ferretti G.M (2001). The External Wealth of Nations: Estimates of Foreign Assets and Liabilities for Industrial and Developing Countries, Journal of International Economics 55:2, 263-294. (2016).

McKinnon, R. I. (1973). Money and Finance in Economic Development, Brookings Institution Press, 1973.

Mun, C. W., Jinjarak, Y. and Rana, P. (2009). The Trend of Trade, Foreign Direct Investment, and Monetary Flows in East Asia, and its Policy Implication: Managing Net Foreign Assets in East Asia On Accumulating Net Foreign Assets: Overview, Possible Consequences and Estimation.

Obstfeld, M. and Rogoff, K. (1995), "The Intertemporal Approach to the Current Account," in Handbook of International Economics, vol. 3, edited by Gene M. Grossman and Kenneth Rogoff, Amsterdam: Elsevier Science Publishers.

Obstfeld, M. and Rogoff, K. (1996), Foundations of International Macroeconomics, Cambridge, MA: MIT Press.

Ohlin, B. (1929). The Reparation Problem: A Discussion. I. Transfer Difficulties, Real and Imagined"; "Mr. Keynes' views on the Transfer Problem. II. A Rejoinder," Economic Journal 39 (June) 172-82; September, 400-404. 
Phillips, P. C. B. and Loretan, M. (1991). Estimating Long-Run Economic Equilibria, Review of Economic Studies 58, May, 407-36.

Roodman, D., (2009). A Note on the Theme of Too Many Instruments, Oxford Bulletin of Economics and Statistics, Vol. 71 (1), pp. 135-58.

Reinhart C. M., Tokatlidis I., (2003). Financial Liberalisation: The African Experience, Journal of African Economies; 12:53-88.

Rogoff, K. (1996). The Purchasing Power Parity Puzzle, Journal of Economic Literature 34, June 647-68.

Shaw, E., S. (1973), Financial Deepening in Economic Development, Oxford University Press, Solanes, J. G. and Flores, F. T. (2008). The Balassa-Samuelson Hypothesis in Developed Countries and Emerging Market Economies: Different Outcomes Explained.Economic Discussion Papers, 2008-14.

Stockman, A. C. and Tesar, L .L. (1995). Tastes and Technology in a Two-Country Model of the Business Cycle: Explaining International Co-movements, American Economic Review $85,168-185$.

Wang, W., Xue, J. and Du, C. (2016). The Balassa-Samuelson Hypothesis in the Developed and Developing Countries Revisited. Economics Letters. http://dx.doi.org/10.1016/j.econlet.2016.07.020 
IBHAGUI Transfer Problem in Sub-Saharan Africa

\section{Appendix}

B.1 SSA countries according to openness to trade

\begin{tabular}{|l|r|l|r|l|r|}
\hline \multicolumn{2}{|c|}{ Low Openness (\%) } & \multicolumn{2}{c|}{ Medium Openness (\%) } & \multicolumn{2}{c|}{ Large Openness (\%) } \\
\hline Country & Openness & Country & Openness & Country & Openness \\
\hline Burundi & 27.62 & Rwanda & 52.28 & Angola & 115.60 \\
\hline Benin & 32.33 & Sudan & 52.81 & Botswana & 98.70 \\
\hline Burkina Faso & 32.47 & Senegal & 55.13 & Cote d'Ivoire & 73.50 \\
\hline CAF & 35.28 & Sierra Leone & 55.19 & Congo, Rep. & 111.32 \\
\hline Cameroon & 37.63 & Chad & 58.47 & Eritrea & 70.95 \\
\hline Ethiopia & 42.60 & Tanzania & 59.86 & Gabon & 91.74 \\
\hline Ghana & 43.04 & Uganda & 59.97 & Gambia & 79.26 \\
\hline Guinea & 44.10 & Yemen, Rep. & 60.84 & Equatorial Guinea & 204.38 \\
\hline Guinea-Bissau & 45.51 & South Africa & 61.46 & Liberia & 139.26 \\
\hline Kenya & 47.53 & DRC & 62.73 & Lesotho & 133.27 \\
\hline Madagascar & 47.62 & Zambia & 65.12 & Mauritania & 90.84 \\
\hline Mali & 47.68 & Zimbabwe & 65.34 & Mauritius & 117.50 \\
\hline Mozambique & 47.93 & & & Namibia & 99.16 \\
\hline Malawi & 48.13 & & & South Sudan & 75.94 \\
\hline Niger & 51.19 & & Swaziland & 142.94 \\
\hline Nigeria & 51.62 & & & Seychelles & 116.85 \\
\hline & & & & & 87.01 \\
\hline
\end{tabular}

Note: Openness, in \%, is computed as $\frac{E x p+I M P}{G D P}$. We define high openness group as one where countries have an average openness which exceeds global average openness. The low openness group comprises countries whose average openness is below 20 percentage points less than the global average openness while the medium openness group is composed of countries with average openness more than 20 percentage points below the global average. The global average openness is the average trade openness of all countries that participate in international trade while the average trade openness of each country is the country's average openness since actively participating in global trade. See the appendix for a summary of the countries in the high, medium and low openness groups. Global average is $71.96 \%$. The number of countries listed here is clearly more than the number of countries considered in our analysis. We have just listed the countries in order to compare their openness to the global average. 
B.2 Country and Year of Financial Liberalization

\begin{tabular}{|l|l|l|l|l|l|}
\hline S/N & Country & FLIB Year & S/N & Country & FLIB Year \\
\hline 1 & Angola & 1991 & 19 & Malawi & 1986 \\
\hline 2 & Benin & 1989 & 20 & Mali & 1987 \\
\hline 3 & Botswana & 1991 & 21 & Mauritania & 1988 \\
\hline 4 & Burkina Faso & 1987 & 22 & Mauritius & 1993 \\
\hline 5 & Burundi & 1990 & 23 & Mozambique & 1992 \\
\hline 6 & Cameroon & 1990 & 24 & Namibia & 1991 \\
\hline 7 & Central Africa Rep. & 1988 & 25 & Niger & 1987 \\
\hline 8 & Chad & 1990 & 26 & Nigeria* & 1987 \\
\hline 9 & Congo Rep & 1988 & 27 & Rwanda & 1994 \\
\hline 10 & Côte d'Ivoire & 1989 & 28 & Senegal & 1987 \\
\hline 11 & Equatorial Guinea & 1995 & 29 & Seychelles & 1992 \\
\hline 12 & Ethiopia & 1992 & 30 & Sierra Leone & 1992 \\
\hline 13 & Gabon & 1988 & 31 & South Africa & 1980 \\
\hline 14 & Gambia & 1988 & 32 & Swaziland & 1994 \\
\hline 15 & Ghana & 1986 & 33 & Tanzania & 1991 \\
\hline 16 & Guinea-Bissau & 1995 & 34 & Togo & 1987 \\
\hline 17 & Kenya & 1993 & 35 & Uganda & 1985 \\
\hline 18 & Madagascar & 1992 & 36 & Zambia & 1992 \\
\hline
\end{tabular}

Note: Dates of financial liberalization (FLIB Year) come from a combination of different sources which include countries' websites, news fillings, and other internet sources, and from multiple previous studies such as Reinhart and Tokatlidis (2000), Seek and El Nil (1993), Fowowe (2008). Some countries such as Nigeria adopted financial liberalization in 1987, reversed the policy a few years later in 1992 and then finally readopted it in 1995. For those years in which financial liberalization was reversed, the financial liberalization variable takes a value of zero, and one otherwise. Of course, because we pull data from multiple sources, there are conflicting information on the adoption of financial liberalization and some of the countries have some discrepancies in the financial liberalization adoption dates, but these dates are not far apart for the countries, so deviations are negligible. 
IBHAGUI Transfer Problem in Sub-Saharan Africa

B.3: Average Real Exchange Rates Before and After Financial Liberalization - Full Countries in the Sample

\begin{tabular}{|c|c|c|c|c|c|}
\hline Country & $\begin{array}{l}\text { Average Real } \\
\text { Exchange } \\
\text { Rate Before } \\
\text { FLIB }\end{array}$ & $\begin{array}{c}\text { Average Real } \\
\text { Exchange } \\
\text { Rate After } \\
\text { FLIB }\end{array}$ & Country & $\begin{array}{c}\text { Average } \\
\text { Real } \\
\text { Exchange } \\
\text { Rate Before } \\
\text { FLIB }\end{array}$ & $\begin{array}{c}\text { Average Real } \\
\text { Exchange } \\
\text { Rate After } \\
\text { FLIB }\end{array}$ \\
\hline Angola & 102.78 & 92.76 & Benin & 118.57 & 95.36 \\
\hline Botswana & 106.23 & 101.92 & Burundi & 212.32 & 125.95 \\
\hline Burkina Faso & 192.5 & 106.04 & Cameroon & 134.59 & 101.68 \\
\hline CAF & 176.37 & 108.31 & Chad & 162.78 & 109.02 \\
\hline Congo & 251.93 & 105.68 & Côte d'Ivoire & 115.72 & 98.01 \\
\hline Gabon & 182.64 & 116.82 & $\begin{array}{l}\text { Equip. } \\
\text { Guinea }\end{array}$ & 75.33 & 85.23 \\
\hline Gambia & 240.46 & 134.92 & Ethiopia & 215.89 & 103.52 \\
\hline Ghana & 504.6 & 104.68 & Nigeria & 1451.00 & 3022.00 \\
\hline $\begin{array}{l}\text { Guinea- } \\
\text { Bissau }\end{array}$ & 163.98 & 95.97 & Rwanda & 177.15 & 114.61 \\
\hline Kenya & 93.48 & 92.04 & Seychelles & 130.99 & 122.92 \\
\hline Madagascar & 187.69 & 104.15 & Sierra Leone & 172.83 & 118.08 \\
\hline Malawi & 206.03 & 135.65 & Swaziland & 106.48 & 97.63 \\
\hline Mali & 169.82 & 112.16 & Tanzania & 282.65 & 120.85 \\
\hline Mauritania & 209.72 & 115.81 & Senegal & 152.28 & 106.65 \\
\hline Mauritius & 118.65 & 112.22 & South Africa & 168.94 & 115.13 \\
\hline Mozambique & 248.345 & 105.11 & Togo & 140.23 & 101.65 \\
\hline Namibia & 108.99 & 97.85 & Uganda & 154.81 & 113.02 \\
\hline Niger & 174.49 & 106.89 & Zambia & 158.57 & 106.98 \\
\hline
\end{tabular}




\section{B.4: Extended Robustness Checks with additional variables}

i. RER, FLIB, and NFA with real gold price (G) and two additional estimators - FE and System GMM.

\begin{tabular}{|c|c|c|c|c|c|}
\hline & $\begin{array}{l}\text { Fixed } \\
\text { Effect }\end{array}$ & $\begin{array}{l}\text { Random } \\
\text { Effect }\end{array}$ & $\begin{array}{l}\text { Bias corrected } \\
\text { LSDV }\end{array}$ & $\begin{array}{l}\text { System } \\
\text { GMM }\end{array}$ & $\begin{array}{l}\text { Difference } \\
\text { GMM }\end{array}$ \\
\hline \multirow[t]{2}{*}{ Lag RER } & & & $0.84 * * *$ & $0.87^{* * *}$ & $0.83 * * *$ \\
\hline & & & $(53.06)$ & $(120.82)$ & $(66.61)$ \\
\hline \multirow[t]{2}{*}{ FLIB } & $-0.17 * * *$ & $-0.17 * * *$ & $-0.024 * * *$ & $-0.02 * *$ & $-0.03 * * *$ \\
\hline & $(14.99)$ & $(15.44)$ & $(3.73)$ & $(2.47)$ & $(3.03)$ \\
\hline \multirow[t]{2}{*}{$N F A$} & $0.01 *$ & $0.01 * *$ & $0.01 * *$ & $0.003^{* *}$ & 0.004 \\
\hline & $(1.84)$ & $(2.10)$ & $(2.10)$ & $(2.07)$ & $(1.42)$ \\
\hline \multirow[t]{2}{*}{$R E L$} & $0.15^{* * *}$ & $0.04 *$ & 0.013 & -0.001 & $0.03 *$ \\
\hline & (3.97) & $(1.82)$ & $(0.66)$ & $(0.50)$ & $(1.90)$ \\
\hline \multirow[t]{2}{*}{$T T$} & $0.10^{* * *}$ & $0.14 * * *$ & $0.04 * *$ & $0.04 * * *$ & $0.042 * *$ \\
\hline & (2.64) & $(3.94)$ & $(2.03)$ & $(3.47)$ & $(2.33)$ \\
\hline Adj. $R^{2}$ & 7.36 & 14.46 & & & \\
\hline Observation & 1099 & 1099 & & 1006 & 996 \\
\hline AR-2 & & & & 0.151 & 0.149 \\
\hline \multicolumn{2}{|l|}{ Hausman Test } & 0.0161 & & & \\
\hline Sargan Test & & & & 0.499 & 0.096 \\
\hline
\end{tabular}

\begin{tabular}{|l|c|c|c|c|c|}
\hline & Fixed Effec & $\begin{array}{c}\text { Random } \\
\text { Effect }\end{array}$ & $\begin{array}{c}\text { Bias corrected } \\
\text { LSDV }\end{array}$ & $\begin{array}{c}\text { System } \\
\text { GMM }\end{array}$ & $\begin{array}{c}\text { Difference } \\
\text { GMM }\end{array}$ \\
\hline Lag RER & & & $0.84^{* * *}$ & $0.87^{* * *}$ & $0.83^{* * *}$ \\
\hline & & & $(52.88)$ & $(121.4)$ & $(67.08)$ \\
\hline FLIB & $-0.16^{* * *}$ & $-0.16^{* * *}$ & $-0.02^{* * *}$ & $-0.018^{* *}$ & $-0.026^{* * *}$ \\
\hline & $(13.20)$ & $(13.68)$ & $(3.50)$ & $(2.40)$ & $(3.00)$ \\
\hline NFA & 0.01 & 0.01 & $0.005^{*}$ & $0.002^{*}$ & 0.003 \\
\hline & $(1.24)$ & $(1.51)$ & $(1.94)$ & $(1.87)$ & $(1.23)$ \\
\hline$R E L$ & $0.15^{* * *}$ & $0.05^{*}$ & 0.014 & -0.001 & $0.029^{* *}$ \\
\hline & $(4.04)$ & $(1.94)$ & $(0.68)$ & $(0.49)$ & $(2.05)$ \\
\hline$T T$ & $0.07^{*}$ & $0.18^{* * *}$ & $0.039^{*}$ & $0.04^{* * *}$ & $0.038^{* *}$ \\
\hline$G$ & $(1.88)$ & $(3.12)$ & $(1.84)$ & $(3.35)$ & $(2.01)$ \\
\hline & $0.08^{* *}$ & $0.08^{* *}$ & 0.01 & $0.014^{*}$ & 0.013 \\
\hline & $(2.44)$ & $(2.40)$ & $(0.43)$ & $(1.70)$ & $(1.23)$ \\
\hline
\end{tabular}


IBHAGUI Transfer Problem in Sub-Saharan Africa

B4 i. Continued

\begin{tabular}{|l|c|c|c|c|c|}
\hline & Fixed Effect & $\begin{array}{c}\text { Random } \\
\text { Effect }\end{array}$ & $\begin{array}{c}\text { Bias corrected } \\
\text { LSDV }\end{array}$ & $\begin{array}{c}\text { System } \\
\text { GMM }\end{array}$ & $\begin{array}{c}\text { Difference } \\
\text { GMM }\end{array}$ \\
\hline AR-2 & & & & 0.15 & 0.148 \\
\hline Sargan Test & & & & 0.488 & 0.089 \\
\hline Adj. $\boldsymbol{R}^{\mathbf{2}}$ & 7.45 & 14.46 & & & \\
\hline Observation & 1,099 & 1,099 & & 1,006 & 966 \\
\hline Hausman Test & 0.0134 & & & & \\
\hline
\end{tabular}

ii. RER, FLIB and NFA with interaction terms and two additional estimators - FE and System GMM

\begin{tabular}{|c|c|c|c|c|c|}
\hline & Fixed Effect & $\begin{array}{l}\text { Random } \\
\text { Effect }\end{array}$ & $\begin{array}{l}\text { Bias-corrected } \\
\text { LSDV }\end{array}$ & $\begin{array}{l}\text { System } \\
\text { GMM }\end{array}$ & $\begin{array}{l}\text { Difference } \\
\text { GMM }\end{array}$ \\
\hline \multirow[t]{2}{*}{$\operatorname{Lag} R E R$} & & & 0.83 & 0.87 & 0.77 \\
\hline & & & $(53.02)$ & (89.19) & $(52.55)$ \\
\hline \multirow[t]{2}{*}{$F L I B$} & $-0.20 * * *$ & $-0.21 * * *$ & $-0.04 * * *$ & $-0.03 * * *$ & $-0.04 * * *$ \\
\hline & $(12.09)$ & $(13.12)$ & $(4.23)$ & $(3.04)$ & $(3.17)$ \\
\hline \multirow[t]{2}{*}{$N F A$} & $0.05^{* * *}$ & $0.06^{* * *}$ & $0.02 * * *$ & $0.02 * * *$ & $0.03 * *$ \\
\hline & $(3.10)$ & $(3.84)$ & $(2.79)$ & $(2.55)$ & $(2.19)$ \\
\hline \multirow[t]{2}{*}{$R E L$} & $0.13 * *$ & 0.03 & 0.002 & 0.000016 & 0.0089 \\
\hline & $(3.22)$ & $(1.28)$ & $(0.10)$ & $(0.09)$ & $(0.23)$ \\
\hline \multirow[t]{2}{*}{$T T$} & $0.10^{* * *}$ & $0.14 * * *$ & $0.04 * *$ & $0.04 * * *$ & $0.084 * * *$ \\
\hline & $(2.74)$ & $(3.93)$ & $(2.14)$ & (4.34) & $(2.85)$ \\
\hline \multirow[t]{2}{*}{$(N F A \times F L I B)$} & $-0.04 * * *$ & $-0.05 * * *$ & $-0.019 * *$ & $-0.01 * *$ & $-0.023 * *$ \\
\hline & $(2.68)$ & $(3.36)$ & $(2.28)$ & $(2.13)$ & $(2.08)$ \\
\hline $\operatorname{Adj} R^{2}$ & 9.38 & 16.02 & & & \\
\hline Observation & 1,099 & 1,099 & & 1,066 & 958 \\
\hline AR-2 & & & & 0.18 & 0.18 \\
\hline Hausman Test & 0.026 & & & & \\
\hline \multirow[t]{2}{*}{ Sargan Test } & & & & 0.134 & 0.074 \\
\hline & Fixed Effect & $\begin{array}{c}\text { Random } \\
\text { Effect }\end{array}$ & $\begin{array}{c}\text { Bias-corrected } \\
\text { LSDV } \\
\end{array}$ & $\begin{array}{l}\text { System } \\
\text { GMM }\end{array}$ & $\begin{array}{l}\text { Difference } \\
\text { GMM }\end{array}$ \\
\hline \multirow[t]{2}{*}{ Lag RER } & & & $0.84 * * *$ & $0.87^{* * *}$ & $0.78^{* * *}$ \\
\hline & & & $(51.83)$ & $(102.86)$ & $(67.71)$ \\
\hline
\end{tabular}


B4 ii. Continued

\begin{tabular}{|c|c|c|c|c|c|}
\hline & Fixed Effect & $\begin{array}{c}\text { Random } \\
\text { Effect }\end{array}$ & $\begin{array}{c}\text { Bias-corrected } \\
\text { LSDV } \\
\end{array}$ & $\begin{array}{l}\text { System } \\
\text { GMM }\end{array}$ & $\begin{array}{l}\text { Difference } \\
\text { GMM }\end{array}$ \\
\hline \multirow[t]{2}{*}{$F L I B$} & $-0.18 * * *$ & $-0.20 * * *$ & $-0.04 * * *$ & $-0.02 * * *$ & $-0.04 * * *$ \\
\hline & $(10.21)$ & $(11.38)$ & $(3.53)$ & $(2.65)$ & (3.30) \\
\hline \multirow[t]{2}{*}{$N F A$} & $0.05^{* * *}$ & $0.06^{* * *}$ & $0.02 * *$ & $0.011^{*}$ & $0.03 * *$ \\
\hline & (3.03) & $(3.83)$ & $(2.02)$ & $(1.85)$ & $(2.06)$ \\
\hline \multirow[t]{2}{*}{$R E L$} & $0.15 * * *$ & 0.04 & 0.01 & 0.000318 & 0.03 \\
\hline & $(3.44)$ & $(1.63)$ & $(0.25)$ & $(0.16)$ & $(0.82)$ \\
\hline \multirow[t]{2}{*}{$T T$} & $0.08^{*}$ & $0.12 * * *$ & $0.04^{*}$ & $0.04 * * *$ & $0.09 * * *$ \\
\hline & (1.90) & (2.98) & $(1.93)$ & $(4.21)$ & $(2.97)$ \\
\hline \multirow[t]{2}{*}{ RIRD } & $-0.003 * * *$ & $-0.003 * * *$ & -0.0004 & -0.0001 & 0.000127 \\
\hline & $(3.80)$ & $(3.90)$ & $(1.07)$ & $(0.19)$ & $(0.20)$ \\
\hline \multirow[t]{2}{*}{$(N F A \times F L I B)$} & $-0.04 * * *$ & $-0.05^{* * *}$ & $-0.0143^{*}$ & -0.01 & $-0.02 *$ \\
\hline & $(2.72)$ & $(3.46)$ & $(1.66)$ & $(1.47)$ & $(1.91)$ \\
\hline \multirow[t]{2}{*}{$(R I R D \times F L I B)$} & $0.003 * * *$ & $0.003 * * *$ & $0.001 *$ & 0.0005 & 0.000362 \\
\hline & $(3.55)$ & $(3.73)$ & $(1.92)$ & $(0.86)$ & $(0.51)$ \\
\hline AR-2 & & & & 0.153 & 0.162 \\
\hline Sargan Test & & & & 0.423 & 0.08 \\
\hline Adj $\boldsymbol{R}^{2}$ & 8.89 & 0.15 & & & \\
\hline Observation & 1,034 & 1,034 & & 994 & 915 \\
\hline Hausman Test & 0.7046 & & & & \\
\hline
\end{tabular}

Robustness checks by varying instrument counts and controlling for additional variables. $* * *, * *, *$ denote statistical significance at the $1 \%, 5 \%$, and $10 \%$ levels respectively. The figures in parenthesis ( ) are modulus $\mathrm{z}$ ratios while figures in brackets [ ] are p-values. 
IBHAGUI Transfer Problem in Sub-Saharan Africa

Summary Statistics

\begin{tabular}{|c|c|c|c|c|}
\hline Variable & Mean & $\begin{array}{l}\text { Standard } \\
\text { Dev }\end{array}$ & Min & Max \\
\hline$R E R$ & 2.09 & 0.21 & 1.47 & 4.75 \\
\hline$F L I B$ & 0.69 & 0.46 & 0 & 1 \\
\hline$N F A$ & -0.66 & 1.32 & -4.07 & 17.21 \\
\hline$T T$ & 0.04 & 0.16 & -0.67 & 0.55 \\
\hline$R E L$ & -0.91 & 0.49 & -1.99 & 0.02 \\
\hline$R I R$ & -0.49 & 14.78 & -100.55 & 71.08 \\
\hline
\end{tabular}

Real exchange rates, represented as real effective exchange rates, terms of trade and relative output per capita are expressed in logarithm while financial liberalization takes 1 in the year financial liberalization begins, 0 otherwise, and net foreign assets position and real interest rates differentials are not expressed in logarithm to specify the reduced form empirical model in line with the theoretical structural model. 